\title{
Combining molecular targeted agents with radiation therapy for malignant gliomas
}

This article was published in the following Dove Press journal:

OncoTargets and Therapy

8 August 2013

Number of times this article has been viewed

\author{
Claudia Scaringi' \\ Riccardo Maurizi Enrici' \\ Giuseppe Minniti ${ }^{1,2}$ \\ 'Department of Radiation Oncology, \\ Sant'Andrea Hospital, University \\ Sapienza, Rome, Italy; ${ }^{2}$ Department of \\ Neuroscience, Neuromed Institute, \\ Pozzilli, Italy
}

\begin{abstract}
The expansion in understanding the molecular biology that characterizes cancer cells has led to the rapid development of new agents to target important molecular pathways associated with aberrant activation or suppression of cellular signal transduction pathways involved in gliomagenesis, including epidermal growth factor receptor, vascular endothelial growth factor receptor, mammalian target of rapamycin, and integrins signaling pathways. The use of antiangiogenic agent bevacizumab, epidermal growth factor receptor tyrosine kinase inhibitors gefitinib and erlotinib, mammalian target of rapamycin inhibitors temsirolimus and everolimus, and integrin inhibitor cilengitide, in combination with radiation therapy, has been supported by encouraging preclinical data, resulting in a rapid translation into clinical trials. Currently, the majority of published clinical studies on the use of these agents in combination with radiation and cytotoxic therapies have shown only modest survival benefits at best. Tumor heterogeneity and genetic instability may, at least in part, explain the poor results observed with a single-target approach. Much remains to be learned regarding the optimal combination of targeted agents with conventional chemoradiation, including the use of multipathways-targeted therapies, the selection of patients who may benefit from combined treatments based on molecular biomarkers, and the verification of effective blockade of signaling pathways.
\end{abstract}

Keywords: glioblastoma, high-grade glioma, targeted therapy, radiation therapy, temozolomide

\section{Introduction}

Glioblastoma (GBM) is the most common malignant primary brain tumor in adults, with an incidence of approximately 2.8 cases per 100,000 person-years. ${ }^{1}$ The current standard of care consists of surgical resection followed by radiotherapy (RT), with concomitant and adjuvant chemotherapy using the alkylating agent temozolomide (TMZ); however, the prognosis remains poor with a reported median and 2-year survival rates of 14.6 months and $26.5 \%$, respectively. ${ }^{2}$

To improve survival, several targeted agents used alone or in combination with RT and/or cytotoxic chemotherapy have been explored as potential inhibitors of the molecular and signal transduction pathways involved in gliomagenesis. Novel therapeutic strategies against newly diagnosed or progressive GBM include tyrosine kinases inhibitors (TKIs) and monoclonal antibodies directed against the epidermal growth factor receptor (EGFR), the vascular endothelial growth factor receptor (VEGFR), the platelet growth factor receptor (PDGFR), inhibitors of mammalian target of rapamycin (mTOR), and integrins molecular pathways. ${ }^{3-14}$
Correspondence: Giuseppe Minniti Department of Radiation Oncology, Sant'Andrea Hospital, Via di

Grottarossa 1035, 00189 Roma, Italy

Tel +39063 3776034

Fax +390633776608

Email gminniti@ospedalesantandrea.it 
Bevacizumab (Avastin ${ }^{\circledR}$; Genentech, Inc, San Francisco, CA, USA), a humanized murine monoclonal antibody directed against vascular endothelial growth factor (VEGF), has received accelerated approval for the treatment of recurrent GBM in 2009 by the US Food and Drug Administration (FDA); however, most of the prospective studies on the use of targeted drugs as single agent for progressive disease have not shown improved clinical outcomes. ${ }^{15}$ Emerging data show that aberrant expression of a variety of cell and molecular pathways may influence radiation resistance, including growth factor receptor signaling pathways, deoxyribonucleic acid (DNA) damage repair processes, and angiogenesis (Figure 1). So far, the combination of RT with simultaneous administration of targeted agents that inhibit molecular pathways involved in tumor growth and progression may represent an attractive strategy against cancer. While this multimodal treatment has shown promising results for different solid cancers - including head and neck, as well as non-small-cell lung cancer (NSCLC) ${ }^{16,17}$ - only limited data are available on the combinations of targeted drugs and RT for GBMs. In this review, we will provide an overview of published studies as well as ongoing trials evaluating the efficacy of targeted therapies in combination with cytotoxic chemotherapy and/or RT for the treatment of newly diagnosed and recurrent GBM.

\section{Combinations of VEGF inhibitors with radiation}

Angiogenesis and its major regulator, VEGF, represent one of the most important therapeutic targets in GBM treatment,

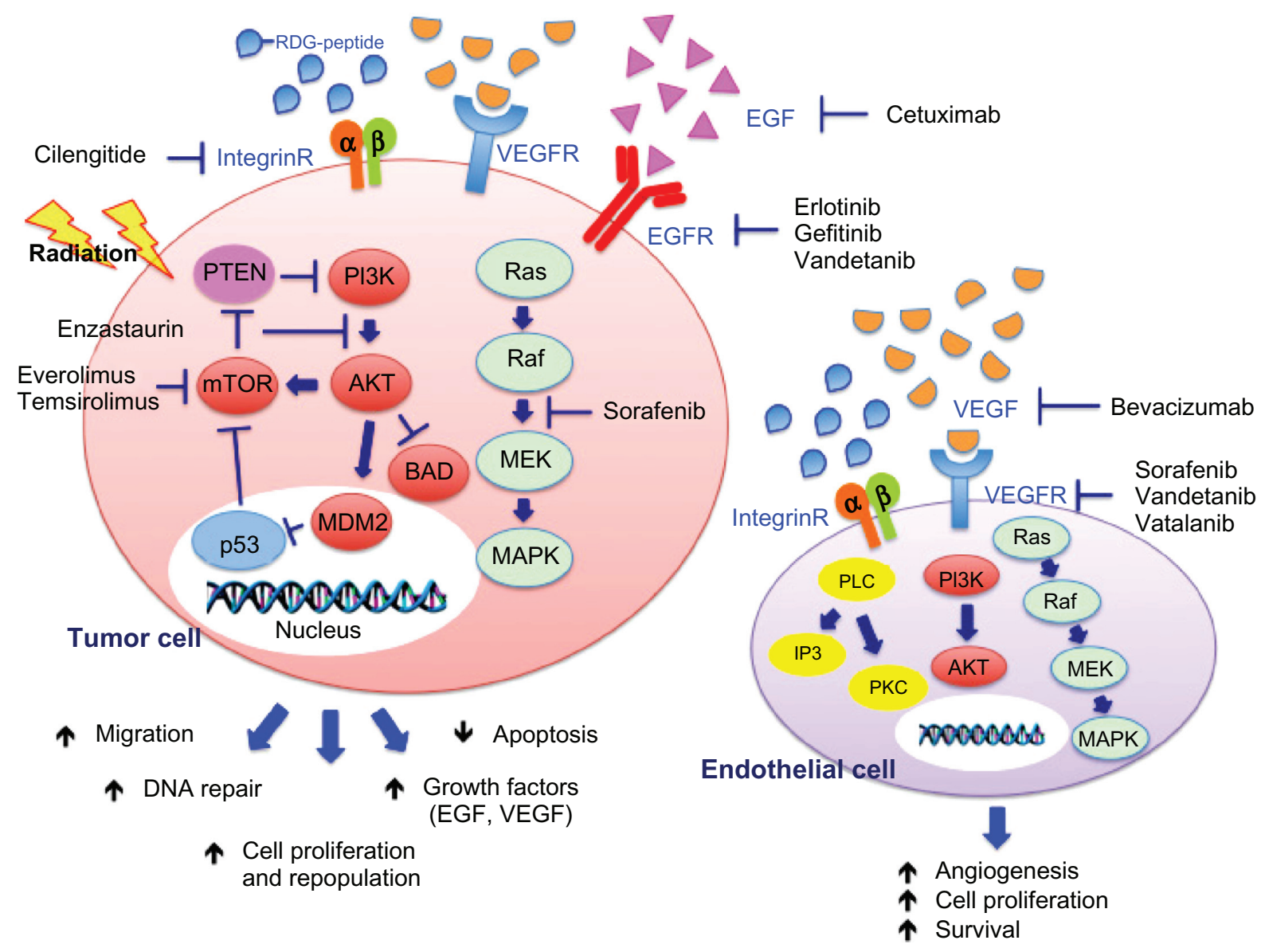

Figure I Schematic representation of the effects of radiation and targeted agents on EGFR, VEGFR, and integrin-signaling pathways.

Notes: After stimulation by irradiation, activation of EGFR, VEGFR, and integrin receptors results in stimulation of downstream signaling pathways that can promote cell survival and proliferation, DNA repair, and angiogenesis in both glioma and endothelial cells. Targeted agents that block at various steps the interaction of EGF (cetuximab), VEGF (bevacizumab), and extracellular proteins containing the RDG-peptide (cilengitide) with their receptor and downstream effectors (EGFR inhibitor erlotinib and gefitinib, VEGFR inhibitor vandetanib, vatalanib and sorafenib, PKC-B inhibitor enzastaurin, and mTOR inhibitors everolimus and temsirolimus) may enhance the damaging effects of irradiation. Abbreviations: EGFR, epidermal growth factor receptor; VEGFR, vascular endothelial growth factor receptor; RDG-peptide, Arg-Gly-Asp peptide; EGF, epidermal growth factor; VEGF, vascular endothelial growth factor; integrin-R, integrin receptor; PTEN, phosphatase and tensin homologue; PI3K, phosphoinositide 3-kinase; Ras, Ras GTPase; mTOR, mammalian target of rapamycin; AKT, protein kinase B; Raf, rapidly accelerated fibrosarcoma; p53, tumor protein 53; MDM2, mouse double minute 2 homologue; BAD, Bcl-2-associated death promoter; MEK, mitogen-activated protein kinase kinase; MAPK, mitogen-activated protein kinase; PLC, phospholipase C; IP3, inositol trisphosphate; PKC, protein kinase C; DNA, deoxyribonucleic acid. 
and the interaction between VEGFR-signaling pathways and RT has been investigated in in vitro and in vivo studies. ${ }^{18-23}$ Upregulation of VEGF expression has been observed in either irradiated GBM cell lines or xenografts, ${ }^{21,23}$ and its overexpression correlates with poor prognosis. ${ }^{24}$ Several tumor cell lines, including U251, U251-NG2, and U87 human GBM cells showed a dose-dependent increase in VEGF levels after single doses of radiation, leading to tumor cell invasion and migration through activation of proto-oncogene tyrosine-protein kinase Src, and focal adhesion kinase. In addition, radiation-induced VEGF secretion may contribute to the high radioresistance of GBM through the reduction of the damaging effect of RT on endothelial cells and increased tumor hypoxia. ${ }^{18,20}$ Several VEGF/VEGFR inhibitors have been recently developed, including bevacizumab, vatalanib (PTK787/ZK222584; Bayer Schering Pharma AG, Berlin, Germany; Novartis Corporation, East Hanover, NJ, USA), cediranib (Recentin ${ }^{\mathrm{TM}}$; AstraZeneca Pharmaceuticals, London, UK), sunitinib (Sutent ${ }^{\circledR}$; Pfizer, Inc, New York, NY, USA), sorafenib (Nexavar ${ }^{\circledR}$, Bayer HealthCare Pharmaceuticals, Inc, Wayne, NJ, USA), vandetanib (Caprelsa $^{\circledR}$; AstraZeneca Pharmaceuticals), and aflibercept (VEGF-Trap; Regeneron Pharmaceuticals, Inc, Tarrytown, NY, USA; Sanofi-Aventis, Paris, France). Clinical studies so far are testing the efficacy of combining VEGFR antagonists with RT, with the potential to improve outcomes by blocking the effects of radiation-induced VEGF expression and by improving tumor oxygenation through vascular normalization.

\section{Bevacizumab}

Bevacizumab is a recombinant humanized monoclonal antibody that inhibits tumor angiogenesis by targeting soluble VEGF-A and preventing its interaction with VEGF receptors. ${ }^{25}$ The antiangiogenic activity of bevacizumab has been demonstrated in several preclinical cancer models. ${ }^{26}$ Inhibition of angiogenesis may be exerted through different mechanisms, including regression of existing tumor vasculature, normalization of surviving vasculature, and inhibition of new and recurrent tumor vessel growth. ${ }^{27-29}$ Bevacizumab has been approved in combination with chemotherapy for use in metastatic colorectal cancer, advanced NSCLC, and advanced and/or metastatic renal cell cancer. ${ }^{30-32}$ Based on the results of two prospective trials, ${ }^{33,34}$ bevacizumab received US FDA accelerated approval as a single-agent for the treatment of recurrent GBM in May 2009.

Preclinical studies have demonstrated that blocking the VEGF pathway with bevacizumab can enhance the sensitivity of both tumor and endothelial cells to the cytotoxic effects of radiation. ${ }^{35,36}$ In tumor xenograft models, the administration of bevacizumab in combination with RT induces inhibition of tumor growth with an additive effect compared to treatment with bevacizumab or radiation alone. ${ }^{36,37}$ The main mechanism by which bevacizumab can enhance the radiation response is by increasing tumor oxygenation through vascular normalization and by improving intratumoral perfusion, as shown in GBM cell lines and in orthotopic U87 GBM xenografts. ${ }^{37-39}$ Interestingly, vascular normalization with improved tumor perfusion and oxygenation was observed only from days 2 to 5 from the start of treatment. Consistent with these findings, the cytotoxic effect of radiation was strongest when RT was delivered within this time interval.

The potential synergistic activity of bevacizumab with RT has been tested in several Phase I and Phase II trials of either newly diagnosed or recurrent gliomas (Table 1). Narayana et $\mathrm{al}^{40}$ have assessed the combination of bevacizumab with standard RT and TMZ in a small series of 15 patients with newly diagnosed high-grade gliomas treated at the New York University Medical Center. Bevacizumab was administered intravenously at $10 \mathrm{mg} / \mathrm{kg}$ on days 14 and 28 of RT, followed by twelve cycles of adjuvant TMZ and bevacizumab $10 \mathrm{mg} / \mathrm{kg}$ every 14 days. At a median followup of 12 months, the 1-year progression-free survival and overall survival rates were $59 \%$ and $86 \%$, respectively. Grade 3-4 toxicities occurred in seven patients and included thromboembolism, multiple nonhealing ulcers, malignant hypertension, and thrombocytopenia/neutropenia. Following these promising results, a further 51 patients with newly diagnosed GBM were treated at the same institution using the same regimen. ${ }^{41}$ The 6 -month and 12 -month progressionfree survival rates were $85 \%$ and $51 \%$, respectively, and the respective overall survival rates were $85 \%$ and $42 \%$. Grade 3 or grade 4 toxicities (thrombocytopenia, deep vein thrombosis, pulmonary embolism, nausea, and fatigue) occurred in $19 \%$ of patients, and asymptomatic intracranial bleeding occurred in $10 \%$ of patients.

Several other prospective studies have assessed the clinical outcomes and toxicity of bevacizumab in association with standard chemoradiation. ${ }^{10,11,42-44}$ Lai et $\mathrm{al}^{11}$ reported a Phase II study of 70 patients treated with bevacizumab plus TMZ during and after RT until tumor progression, or for a maximum of $24 \mathrm{TMZ}$ cycles. Median overall survival and progression-free survival rates were 19.6 months and 13.6 months, respectively, as compared with survivals of 21.1 months and 7.6 months, respectively, in a control cohort of 110 patients treated with standard treatment at University of California and Kaiser Permanente Los 
Table I Clinical trials of antiangiogenic agents and integrin inhibitors in combination with radiotherapy

\begin{tabular}{|c|c|c|c|c|c|c|}
\hline Authors & Reference & Drug & Patients & Tumor & Drug dose & Outcomes \\
\hline Narayana et al & 40 & Bevacizumab & 15 & Newly diagnosed HGGs & $\begin{array}{l}10 \mathrm{mg} / \mathrm{kg} \text { every } 14 \text { days + } \\
\text { RT + TMZ }\end{array}$ & $\begin{array}{l}\text { PFS-12: } 59.3 \% \\
\text { OS-12: } 86.7 \%\end{array}$ \\
\hline Lai et al & 11 & Bevacizumab & 70 & Newly diagnosed GBM & $\begin{array}{l}10 \mathrm{mg} / \mathrm{kg} \text { every } 14 \text { days }+ \\
\text { RT + TMZ }\end{array}$ & $\begin{array}{l}\text { PFS: } 13.6 \text { months } \\
\text { OS: } 19.6 \text { months }\end{array}$ \\
\hline Vredenburgh et al & 10 & Bevacizumab & 75 & Newly diagnosed GBM & $\begin{array}{l}10 \mathrm{mg} / \mathrm{kg} \text { every } 14 \text { days }+ \\
\mathrm{RT}+\mathrm{TMZ}+\text { irinotecan }\end{array}$ & $\begin{array}{l}\text { PFS: } 14.2 \text { months } \\
\text { OS: } 21.2 \text { months }\end{array}$ \\
\hline Vredenburgh et al & 43 & Bevacizumab & 125 & Newly diagnosed GBM & $\begin{array}{l}10 \mathrm{mg} / \mathrm{kg} \text { every } 14 \text { days + } \\
\mathrm{RT}+\mathrm{TMZ}+\text { irinotecan }\end{array}$ & $\begin{array}{l}\text { PFS-6: } 87.2 \% \\
\text { PFS: } 13.8 \text { months }\end{array}$ \\
\hline Narayana et al & 41 & Bevacizumab & 51 & Newly diagnosed GBM & $\begin{array}{l}10 \mathrm{mg} / \mathrm{kg} \text { every } 14 \text { days }+ \\
\mathrm{RT}+\mathrm{TMZ}\end{array}$ & $\begin{array}{l}\text { PFS-12: } 51 \% \\
\text { OS-12: } 85.1 \%\end{array}$ \\
\hline Hainsworth et al & 44 & Bevacizumab & 68 & Newly diagnosed GBM & $\begin{array}{l}10 \mathrm{mg} / \mathrm{kg} \text { every } 14 \text { days }+ \\
\mathrm{RT}+\mathrm{TMZ}+\text { everolimus }\end{array}$ & $\begin{array}{l}\text { PFS: I } 1.3 \text { months } \\
\text { OS: I } 3.9 \text { months }\end{array}$ \\
\hline Shapiro et al & 47 & Bevacizumab & 24 & Recurrent HGGs & $\begin{array}{l}10 \text { mg/kg every } 14 \text { days + } \\
\text { HFSRT ( } 30 \text { Gy) }\end{array}$ & $\begin{array}{l}\text { PFS: } 7.5 \text { months } \\
\text { OS: } 12.2 \text { months }\end{array}$ \\
\hline Niyazi et al & 48 & Bevacizumab & 20 & Recurrent HGGs & $\begin{array}{l}10 \mathrm{mg} / \mathrm{kg} \text { every } 14 \text { days + } \\
\text { RT ( } 36 \mathrm{~Gy})\end{array}$ & $\begin{array}{l}\text { PFS: } 244 \text { days } \\
\text { OS: } 367.6 \text { days }\end{array}$ \\
\hline Hundsberger et al & 49 & Bevacizumab & 14 & Recurrent HGGs & $\begin{array}{l}10 \text { mg/kg every } 14 \text { days + } \\
\text { RT (39-55 Gy) }\end{array}$ & $\begin{array}{l}\text { PFS: } 5.1 \text { months } \\
\text { OS: } 9 \text { months }\end{array}$ \\
\hline Drappatz et al & 65 & Vandetanib & 13 & Newly diagnosed GBM & $\begin{array}{l}100 \mathrm{mg} / \text { day to } 200 \mathrm{mg} / \text { day }+ \\
\mathrm{RT}+\mathrm{TMZ}\end{array}$ & $\begin{array}{l}\text { PFS: } 8 \text { months } \\
\text { OS: II months }\end{array}$ \\
\hline Fields et al & 8 & Vandetanib & 14 & Recurrent HGGs & $\begin{array}{l}100 \mathrm{mg} / \text { day to } 200 \mathrm{mg} / \text { day + } \\
\text { FSRS ( } 36 \mathrm{~Gy})\end{array}$ & $\begin{array}{l}\text { PFS: } 3 \text { months } \\
\text { OS: } 6 \text { months }\end{array}$ \\
\hline Broniscer et al & 66 & Vandetanib & 21 & $\begin{array}{l}\text { Newly diagnosed } \\
\text { pediatric brain tumor }\end{array}$ & $50 \mathrm{mg} / \mathrm{m}^{2}$ to $145 \mathrm{mg} / \mathrm{m}^{2}+\mathrm{RT}$ & OS-12: $37.5 \%$ \\
\hline Brandes et al & 73 & Vatalanib & 19 & Newly diagnosed GBM & $\begin{array}{l}500 \mathrm{mg} / \text { day to } \mathrm{I}, 250 \mathrm{mg} / \text { day + } \\
\mathrm{RT}+\mathrm{TMZ} \\
750 \mathrm{mg} \text { twice/daily + TMZ }\end{array}$ & $\begin{array}{l}\text { PFS: } 6.8 \text { months } \\
\text { OS: } 17.3 \text { months }\end{array}$ \\
\hline Gerstner et al & 9 & Vatalanib & 19 & Newly diagnosed GBM & $\begin{array}{l}250 \mathrm{mg} \text { twice/daily to } 500 \mathrm{mg} \\
\text { twice/daily + RT + TMZ } \\
750 \mathrm{mg} \text { twice/daily + TMZ }\end{array}$ & $\begin{array}{l}\text { PFS: } 7.2 \text { months } \\
\text { OS: } 16.2 \text { months }\end{array}$ \\
\hline Den et al & 83 & Sorafenib & $\begin{array}{l}11 \\
7\end{array}$ & Newly diagnosed HGGs & $\begin{array}{l}200 \mathrm{mg} \text { to } 400 \mathrm{mg} \text { twice/daily }+ \\
\text { RT + TMZ }\end{array}$ & OS: 18 months \\
\hline & & & & Recurrent HGGs & $\begin{array}{l}200 \mathrm{mg} \text { to } 400 \mathrm{mg} \text { twice/daily + } \\
\text { HFSRT ( } 35 \mathrm{~Gy})\end{array}$ & OS: 24 months \\
\hline Butowski et al & 96 & Enzastaurin & 66 & Newly diagnosed GBM & $250 \mathrm{mg} / \mathrm{day}+\mathrm{RT}+\mathrm{TMZ}$ & $\begin{array}{l}\text { PFS: } 36 \text { weeks } \\
\text { OS: } 74 \text { weeks }\end{array}$ \\
\hline Stupp et al & 13 & Cilengitide & 52 & Newly diagnosed GBM & $500 \mathrm{mg} / \mathrm{day}+\mathrm{RT}+\mathrm{TMZ}$ & $\begin{array}{l}\text { PFS- } 6: 69 \% \\
\text { OS: } 16.1 \text { months }\end{array}$ \\
\hline Nabors et al & 14 & Cilengitide & 112 & Newly diagnosed GBM & $\begin{array}{l}500 \mathrm{mg} / \text { day or } 2,000 \mathrm{mg} / \text { day }+ \\
\text { RT + TMZ }\end{array}$ & $\begin{array}{l}\text { PFS: } 9.9 \text { months } \\
\text { OS: } 19.7 \text { months }\end{array}$ \\
\hline
\end{tabular}

Abbreviations: HGGs, high-grade gliomas; RT, radiotherapy; TMZ, temozolomide; PFS-12, 12-month progression-free survival; OS-I2, I2-month overall survival; GBM, glioblastoma; PFS, progression-free survival; OS, overall survival; HFSRT, hypofractionated stereotactic radiation; FSRS, fractionated stereotactic radiosurgery; PFS-6, 6-month progression-free survival.

Angeles, indicating that treatment with bevacizumab and TMZ was associated with improved progression-free survival without improved overall survival. The most common nonhematologic treatment-related toxicities were represented by fatigue, venous thrombosis, hypertension, and proteinuria. Presumed toxicities related to bevacizumab included cerebrovascular ischemia in six patients, wound infections in four patients, gastrointestinal perforations in two patients, gastrointestinal bleeding in two patients, and cerebral hemorrhage in two patients.
Vredenburgh et $\mathrm{a}^{10}$ reported on 75 patients with newly diagnosed GBM treated at Duke University with bevacizumab with concomitant RT and TMZ followed by adjuvant bevacizumab, TMZ, and irinotecan. Bevacizumab was administered during RT every 14 days at a dose of $10 \mathrm{mg} / \mathrm{kg}$. Two weeks after completion of chemoradiation, therapy was continued with 6-12 cycles of TMZ, bevacizumab at a dose of $10 \mathrm{mg} / \mathrm{kg}$ every 14 days, and irinotecan every 14 days at a dose of $125 \mathrm{mg} / \mathrm{m}^{2}$ for patients not on enzyme-inducing antiepileptic drugs (EIAEDs), and $340 \mathrm{mg} / \mathrm{m}^{2}$ for patients 
on EIAEDs. At a median follow-up of 23.1 months, median overall survival and progression-free survival rates were 21.2 months and 14.2 months, respectively. Discontinuation of therapy due to treatment-related toxicity occurred in $4 \%$ of patients during RT and in $23 \%$ of patients during adjuvant chemotherapy. Two patients died, one from neutropenic sepsis and one from pulmonary embolism. Results of the addition of bevacizumab to standard RT and daily TMZ in 125 patients with newly diagnosed GBM have been reported by the same group. ${ }^{43}$ With a median follow-up of 21 months, the median and 6-month progression-free survival rates were 13.8 months and $87.2 \%$, respectively. RT was discontinued in five patients due to pulmonary embolism in two patients, grade 4 pancytopenia in one patient, grade 2 cerebral hemorrhage in one patient, and wound dehiscence in one patient. Grade 4 thrombocytopenia/neutropenia occurred in four patients, and nonhematologic toxicities occurred in a further four patients (two generalized seizures, one pneumocystis carinii pneumonia, and one bowel perforation).

Hainsworth et $\mathrm{al}^{44}$ evaluated the efficacy and safety of the combination of standard RT and TMZ with bevacizumab followed by maintenance therapy with bevacizumab and the mTOR inhibitor, everolimus, in 68 patients with newly diagnosed GBM. The treatment was well tolerated, although median progression-free survival and overall survival rates were 11.3 months and 13.9 months, respectively, which were similar to those reported with standard chemoradiation. ${ }^{2}$

More recently, preliminary results of a Phase III, randomized, double blind, placebo-controlled trial that assessed the efficacy and safety profile of bevacizumab in combination with RT and TMZ chemotherapy following surgery or biopsy in patients with newly diagnosed GBM (the AVAglio study) have been reported. ${ }^{45}$ Patients were randomized to receive: bevacizumab plus RT and TMZ chemotherapy, followed by bevacizumab and TMZ for up to six cycles, followed by bevacizumab alone until disease progression; or RT, TMZ, and placebo for 6 weeks, followed by TMZ and placebo for up to six cycles, followed by placebo until disease progression. Primary endpoints were progression-free survival and overall survival. A 4.4-month improvement in median progressionfree survival was observed in patients who received bevacizumab in combination with RT and TMZ compared to those who received radiation and TMZ plus placebo (10.6 months versus 6.2 months, respectively, $P<0.0001)$. However, interim results for overall survival did not reach statistical significance (hazard ratio $=0.89 ; P=0.2135$ ). The 1 -year survival rates were $66 \%$ for the placebo arm versus $72 \%$ in the bevacizumab arm $(P=0.052)$. Final data on overall survival are expected by the end of 2013. An important finding of the study was that bevacizumab in combination with standard chemoradiation significantly improved the duration of functional independence and a number of selected healthrelated quality of life domains, and significantly decreased corticosteroid doses.

The clinical activity of bevacizumab with RT in the retreatment setting has been evaluated in a few studies. ${ }^{46-49}$ Gutin et $\mathrm{al}^{46}$ reported on 24 patients with recurrent high-grade glioma treated with hypofractionated stereotactic RT (30 Gy in five fractions over 2.5 weeks) and bevacizumab administered at a dose of $10 \mathrm{mg} / \mathrm{kg}$ every 14 days of 28-day cycles until tumor progression. The median progression-free survival and overall survival rates were 7.3 months and 12.5 months for patients with GBM, and 7.5 months and 16.5 months for patients with grade 3 glioma, respectively. Severe treatmentrelated toxicity occurred in three patients and included central nervous system intratumoral hemorrhage, bowel perforation, and wound dehiscence. Similar encouraging data were reported in a retrospective analysis by Niyazi et $\mathrm{al}^{48}$ in 30 patients with recurrent high-grade glioma treated with fractionated stereotactic RT (36 Gy in 18 fractions) alone or in combination with bevacizumab $(10 \mathrm{mg} / \mathrm{kg}$ on days 1 and 15 during RT). The addition of bevacizumab to reirradiation resulted in significant improvement of overall survival (367.6 days versus 187.4 days) and progression-free survival (244 days versus 143 days), as compared with reirradiation alone. Toxicity included one grade 3 deep vein thrombosis, one grade 4 wound healing complication, and two cases of radiation necrosis. Overall, the results of these studies suggest that reirradiation in combination with bevacizumab is a feasible and well tolerated treatment in selected patients with recurrent GBM, although survival benefits are modest.

\section{Vandetanib}

Vandetanib is an oral anilinoquinazoline compound with a low molecular weight that acts as a potent multitargeted inhibitor of VEGFR-2, ${ }^{50}$ EGFR, and the REarranged during Transfection (RET) tyrosine kinases. ${ }^{51,52}$ Therefore, by simultaneous inhibition of both VEGFR and EGFR pathways, vandetanib may exhibit antitumor activity through blockade of multiple mechanisms that are essentials for tumor angiogenesis and proliferation. Several clinical trials evaluated vandetanib as a single agent or in combination with chemotherapy in solid tumors, although with modest survival benefit. ${ }^{53-56}$ Currently, vandetanib has been approved by the US FDA for the treatment of unresectable locally advanced or metastatic medullary thyroid cancer. ${ }^{57}$ 
Preclinical studies have shown that vandetanib combined with radiation inhibits tumor growth in a dose-dependent manner. The mechanism by which the inhibition of VEGFR-2 may potentiate the cytotoxic effect of ionizing radiation is by reducing tumor hypoxia through vascular normalization, ${ }^{35}$ and through decreasing tumor cell oxygen consumption, ${ }^{58}$ as demonstrated in either human GBM cell lines or nude mice xenografts, ${ }^{59}$ as well as in orthotopic rat glioma models. ${ }^{60}$ The optimal timing of the administration of vandetanib with RT has not yet been established, as enhanced inhibition of tumor growth has been shown in different tumor models with both concurrent ${ }^{61}$ and sequential ${ }^{62}$ combined treatment, as well as irrespective of sequencing of both agents..$^{63,64}$

Based on this preclinical evidence, few Phase I studies have investigated the combination of vandetanib with RT in both newly diagnosed and recurrent gliomas (Table 1). Drappatz et al ${ }^{65}$ enrolled 13 patients with newly diagnosed GBM into a Phase I trial testing the combination of vandetanib with standard RT and TMZ. In the initial cohort, six patients were treated with vandetanib at $200 \mathrm{mg} /$ day. Three patients developed dose-limiting toxicities (DLTs), including one patient with grade 5 gastrointestinal hemorrhage and grade 4 thrombocytopenia, one patient with grade 4 neutropenia, and one patient with grade 4 diverticulitis with gastrointestinal perforation. Grade 3 rash and grade 3 diarrhea occurred in two patients requiring dose reduction. No DLTs were observed in seven patients treated at the lower dose of $100 \mathrm{mg} /$ day, establishing this dose as the maximumtolerated dose (MTD). Of the ten patients evaluable for tumor response, nine had stable disease (90\%) and one had progressive disease $(10 \%)$. The median overall survival and progression-free survival rates were 11 months and 8 months, respectively. Fields et $\mathrm{al}^{8}$ reported results of a Phase I doseescalation study for patients with recurrent high-grade glioma treated with fractionated stereotactic radiosurgery (36 Gy in three fractions) and vandetanib given at a dose of $100 \mathrm{mg}$ or $200 \mathrm{mg}$ daily during radiation and thereafter, until a DLT occurred or until disease progression. Of the ten patients evaluable for toxicity, DLTs were observed in one patient receiving vandetanib at a dose of $100 \mathrm{mg}$ daily and in two patients receiving $200 \mathrm{mg}$ daily. At a median follow-up time of 4 months, the median overall survival and progression-free survival rates were 6 months and 3 months, respectively.

The combination of vandetanib with RT was also addressed in children with newly diagnosed diffuse intrinsic pontine gliomas. ${ }^{66}$ In a Phase I study, vandetanib was administered daily from the first day of RT and continued for up to 2 years. The initial dosage was $50 \mathrm{mg} / \mathrm{m}^{2}$ and subsequent dose levels were $65 \mathrm{mg} / \mathrm{m}^{2}, 85 \mathrm{mg} / \mathrm{m}^{2}, 110 \mathrm{mg} / \mathrm{m}^{2}$, and $145 \mathrm{mg} / \mathrm{m}^{2}$ per day. Of the 21 patients evaluated, grade 3 toxicity (diarrhea) was observed in one patient at the dose of $145 \mathrm{mg} / \mathrm{m}^{2}$. Therefore, an expanded cohort of 14 patients was treated at $110 \mathrm{mg} / \mathrm{m}^{2}(\mathrm{n}=10)$ and $145 \mathrm{mg} / \mathrm{m}^{2}(\mathrm{n}=4)$. Two of ten patients treated with $145 \mathrm{mg} / \mathrm{m}^{2}$ developed grade 4 hypertension and posterior reversible encephalopathy syndrome; therefore, the recommended Phase II dose of vandetanib in children was $145 \mathrm{mg} / \mathrm{m}^{2}$ per day. The 1 -year and 2-year overall survival rates for all patients were $37.5 \%$ and $21.4 \%$, respectively, with only three patients who remained alive and free of disease progression for more than 2 years.

\section{Vatalanib}

Vatalanib is an anilino phthalazine compound that displays submicromolar antagonistic activity against all three isoforms of VEGFR, with a higher affinity toward VEGFR-2. In addition, vatalanib selectively inhibits the PDGFR- $\beta$ and c-kit at higher concentrations, ${ }^{67}$ resulting in an additive antitumor effect. ${ }^{68,69}$ The addition of vatalanib to radiation resulted in significantly greater tumor control than either RT or vatalanib treatment alone in either GBM cell lines or tumor xenografts in a dose-dependent manner. ${ }^{70-72}$

Vatalanib combined with RT in newly diagnosed GBM has been evaluated in two Phase I trials (Table 1). The European Organization for Research and Treatment of Cancer performed a Phase I/II trial in 19 patients with newly diagnosed GBM treated with vatalanib combined with standard RT and TMZ. ${ }^{73}$ The starting dose of vatalanib was $500 \mathrm{mg}$ from the first day of RT and subsequent dose levels were 1,000 $\mathrm{mg}$ and 1,250 $\mathrm{mg}$. During adjuvant TMZ therapy, the drug was administered at a dose of $750 \mathrm{mg}$ twice daily until disease progression. No DLTs were observed in the $500 \mathrm{mg}$ arm, while grade 3 hyponatremia $(\mathrm{n}=1)$ and grade 3 liver dysfunction $(n=1)$ were observed in the $1,000 \mathrm{mg}$ group, and grade 3 diarrhea $(n=1)$, grade 3 liver transaminases increases $(\mathrm{n}=2)$, and grade 4 thrombocytopenia and/or neutropenia were observed in the $1,250 \mathrm{mg}$ group. Daily vatalanib at $1,000 \mathrm{mg}$ was the recommended dose for the Phase II study. Despite a promising median progression-free survival and overall survival rates of 6.8 months and 17.3 months, the planned randomized Phase II trial was discontinued right at its onset due to the decision of the industry to discontinue the drug, mainly due to the disappointing results from two Phase III trials in patients with metastatic colorectal cancer. ${ }^{74,75}$ In another Phase I study, 19 patients with newly diagnosed GBM received vatalanib combined with standard RT, TMZ, and an 
EIAED. ${ }^{9}$ Seven patients were treated with vatalanib $250 \mathrm{mg}$ daily, six patients with $250 \mathrm{mg}$ twice daily, and six patients with $500 \mathrm{mg}$ twice daily. Thereafter, during adjuvant chemotherapy patients received a dose of $750 \mathrm{mg}$ of vatalanib twice daily, until tumor progression, patient withdrawal, or unacceptable toxicity. Only two DLTs were reported, including thrombocytopenia in one patient at $250 \mathrm{mg}$ daily and elevated transaminases in one patient at $500 \mathrm{mg}$ twice daily. Other grade 3/4 adverse events included elevated liver transaminases, leukopenia, neutropenia, lymphopenia, and hand-foot syndrome, all in one patient. Of the 13 patients evaluable for a radiographic response, two had a partial response and nine had stable disease. At a median follow-up of 14.9 months, the median progression-free survival and overall survival rates were 7.2 months and 16.2 months, respectively.

\section{Sorafenib}

Sorafenib is a small-molecule TKI that blocks phosphorylation of VEGFR, PDGFR, c-kit, and Raf serine kinase by competing with adenosine triphosphate (ATP) for the ATPbinding site. ${ }^{76}$ Thus, sorafenib prevents the activation of the intracellular signaling pathways, which leads to angiogenesis and induces apoptosis in several tumor cell lines. ${ }^{77}$ Sorafenib has been approved by the US FDA for the treatment of advanced unresectable hepatocellular carcinoma, ${ }^{78}$ as well as for advanced renal cell cancer. ${ }^{79}$

In vitro, sorafenib displays antitumor activity in a dose-dependent manner by inhibition of proliferation, and induction of apoptosis and autophagy in several glioma cell lines, ${ }^{80,81}$ with selective action on cancer stem cells. ${ }^{82}$ In orthotopic GBM xenografts, treatment with sorafenib suppresses tumor growth and angiogenesis, and induces tumor cell apoptosis. ${ }^{80}$ More recently, it has been shown that a combination of sorafenib, TMZ, and irradiation significantly reduces cell viability of human GBM cell lines with a methylated O-6-methylguanine-DNA methyltransferase (MGMT) promoter. ${ }^{83}$ Based on these preclinical data, a Phase I dose escalation trial was conducted to evaluate the safety and efficacy of sorafenib in combination with TMZ and standard RT in patients with newly diagnosed high-grade gliomas, or in combination with hypofractionated stereotactic RT alone (35 Gy in ten fractions) in patients with recurrent high-grade gliomas (Table 1). ${ }^{83}$ Sorafenib was administered orally from the night before the first day of RT, with escalation of dosing from $200 \mathrm{mg}$ twice daily to $400 \mathrm{mg}$ twice daily. Treatment with sorafenib was continued for an additional 30 days after completion of RT at the physician's discretion. The most common grade 3 and 4 toxicities were hematologic (lymphopenia thromboctopenia, anemia) fatigue, and rash, and required discontinuation of treatment with sorafenib in $22 \%$ of patients in the $200 \mathrm{mg}$ arm and in 55\% of patients in the $400 \mathrm{mg}$ arm. The recommended MTD and Phase II dose of sorafenib was $200 \mathrm{mg}$ twice daily when combined with TMZ and RT, and $400 \mathrm{mg}$ twice daily with RT alone. The median survival time was 18 months for all 18 patients, being 18 months for patients with newly diagnosed gliomas, and 24 months for those with recurrent high-grade gliomas.

\section{Enzastaurin}

Protein kinase $\mathrm{C}(\mathrm{PKC})$ is a family of at least twelve isoforms of serine-threonine kinases, which play a central role in regulating cell proliferation, differentiation, apoptosis, and secretion. ${ }^{84,85}$ Increased PKC expression and/or activation have been observed in several tumors. ${ }^{86}$ Among the PKC family members, PKC beta $(\mathrm{PKC}-\beta)$ is a key mediator of the VEGFR-signaling pathway that is specifically involved in tumor-induced angiogenesis and endothelial cell proliferation. ${ }^{87,88}$ Enzastaurin (LY317615; Eli Lilly and Company, Indianapolis, IN, USA) is an acyclic bisindolylmaleimide that selectively blocks the activation of the PKC- $\beta$ at low nanomolar concentrations and suppresses VEGF expression in human tumor xenografts. ${ }^{89,90}$ In addition to its antiangiogenic activity, enzastaurin has also direct proapoptotic and antiproliferative effects through inhibition of the phosphatidylinositol 3-kinase (PI3K/Akt) on various human cancer cells, including GBM cell lines and xenograft tumor tissues. ${ }^{91}$ In vitro and in vivo models have shown that enzastaurin combined with RT synergistically reduces tumor volume and radiation-induced tumor satellite formation, upregulates VEGF expression, and induces tumor-vasculature destruction. ${ }^{92-94}$ In nude mice with orthotopic LNT-229 glioma cells, the addition of enzastaurin to RT reduced radiation-induced tumor satellite formation, thus supporting the crucial role of enzastaurin in preventing the proangiogenic effect of RT.

The safety and clinical activity of enzastaurin in association with standard RT and TMZ treatment in patients with newly diagnosed GBM have been explored in a few clinical trials (Table 1). Butowski et $\mathrm{al}^{95}$ reported a single-institution Phase I dose-escalation trial of enzastaurin with standard chemoradiation in patients with newly diagnosed GBM or gliosarcoma. Enzastaurin was administered at doses of $250 \mathrm{mg}(\mathrm{n}=6)$ or $500 \mathrm{mg}(\mathrm{n}=6)$ daily from the night before the beginning of RT. Thereafter, patients received enzastaurin at $250 \mathrm{mg}$ or $500 \mathrm{mg}$ daily and TMZ for up to twelve cycles until tumor progression or unacceptable toxicity. No DLTs were observed among patients receiving the $250 \mathrm{mg}$ dose, while one grade 3 
and one grade 4 thrombocytopenia was observed in the $500 \mathrm{mg}$ arm. On the basis of this toxicity profile, a Phase II study using enzastaurin at $250 \mathrm{mg}$ daily was conducted in 66 patients with newly diagnosed GBM or gliosarcoma. ${ }^{96}$ Combination therapy was well tolerated and discontinuation of treatment was required in $9 \%$ of patients. Median overall survival and progression-free survival rates were 74 weeks and 36 weeks, respectively. Results were comparable to those observed in historical Phase II studies of erlotinib in association with standard RT and TMZ treatment, ${ }^{4}$ and better than those observed with either thalidomide ${ }^{97}$ or cis-retinoic acid. ${ }^{98}$

\section{Combinations of integrin inhibitors with radiation}

Integrins are a family of heterodimeric transmembrane glycoproteins known to play critical roles in cell-cell adhesion and cell interaction with specific extracellular matrix proteins. Among integrins, the $\alpha v$ integrins, particularly $\alpha v \beta 3$ and $\alpha v \beta 5$, are overexpressed in both tumor-associated vasculature and glioma cells, ${ }^{99,100}$ and their activation triggers pathways involved in tumor-induced angiogenesis, cell proliferation, and survival. ${ }^{101-104}$ The antiangiogenic and antitumor effects of combining integrin inhibitors and radiation have been observed in preclinical models. ${ }^{105-109}$ Blockade of $\alpha v \beta 3$ and $\alpha v \beta 5$ integrins in combination with RT induces apoptosis in endothelial cells in vitro, ${ }^{105,106}$ and inhibits tumor growth in U87 GBM xenografts in vivo. ${ }^{105}$ Moreover, in U87 and SF763 GBM cell lines, targeting $\alpha v \beta 3$ and $\alpha v \beta 5$ integrins significantly reduces cell survival after irradiation. ${ }^{107}$ In vivo models have also shown that the enhanced antitumor effect of combined treatment depends on inhibition of radiationinduced $\alpha \mathrm{v}$ integrins and VEGFR signaling pathways, and activation of apoptosis in both tumor cells and tumor vascular endothelial cells. ${ }^{108}$ In addition, targeting $\alpha v$ integrins enhances blood perfusion and reduces tumor hypoxia, thus increasing tumor response to radiation therapy. ${ }^{109}$

\section{Cilengitide}

Cilengitide (EMD 121974; Merck KgaA, Darmstadt, Germany), is a cyclized Arg-Gly-Glu(RGD)-containing pentapeptide that selectively inhibits $\alpha v \beta 3$ and $\alpha v \beta 5$ integrins at subnanomolar concentrations. ${ }^{110-112}$ Cilengitide has been evaluated in Phase I/II trials as a single agent and in combination with other chemotherapeutic agents in a variety of solid tumors, including prostate, pancreatic, and head and neck cancers. ${ }^{113-115}$ Cilengitide failed to demonstrate any clear survival advantage in these tumors; however, clinical activity was reported in patients with recurrent GBM. ${ }^{116-119}$
In vitro and in vivo studies have demonstrated the potential value of targeting $\alpha v \beta 3$ and $\alpha v \beta 5$ integrins with cilengitide in combination with RT in high-grade gliomas. ${ }^{120,121}$ Cilengitide combined with RT in vivo demonstrated more than doubling of the median survival time ( $>110$ days) as compared to RT alone (50 days). ${ }^{121}$ RT induces expression of $\alpha v \beta 3$ integrins in human umbilical vein endothelial cells, and combined treatment with cilengitide and single-dose irradiation enhances detachment and apoptosis of these cells as compared to cilengitide or RT alone. ${ }^{120}$

Based on the results of preclinical studies, the efficacy and safety of combining cilengitide with RT in patients with newly diagnosed GBM have been assessed in a few recent studies (Table 1). In an initial Phase I/II study of 52 patients who received cilengitide at a dose of $500 \mathrm{mg}$ twice weekly in association with standard chemoradiation, Stupp et $\mathrm{al}^{13}$ reported a median survival of 16.1 months and a 6-month progressionfree survival of $69 \%$. According to the methylation status of the MGMT gene promoter, patients with methylated MGMT promoter had significantly longer progression-free survival and overall survival as compared with those with unmethylated tumors. The treatment regimen was well tolerated. The most common toxicities were thrombocytopenia, intracranial hemorrhage, neuropathy, and idiosyncratic liver toxicity. Thromboembolic events and grade $1 / 2$ hypertension were reported in three patients and five patients, respectively. Discontinuation of therapy due to possible treatment-related toxicity occurred in $14 \%$ of patients.

In a randomized Phase II trial of the New Agents Brain Tumor Treatment cooperative group (NABTT 0306), 112 patients with newly diagnosed GBM were randomized to receive cilengitide at a dose of $500 \mathrm{mg}$ or 2,000 $\mathrm{mg}$ twice weekly concomitantly with standard treatment. ${ }^{14}$ After six cycles of adjuvant TMZ, cilengitide was given as a single agent until tumor progression. Median survival and 2-year survival rates were 19.7 months and 38\%, respectively, with a more favorable trend for patients treated in the $2,000 \mathrm{mg}$ arm. The median progression-free survival was 10 months, with no differences between the two dose groups. Combined treatment was well tolerated with no DLTs observed at any dose level. Interestingly, the trial confirmed a survival benefit for patients who had methylated MGMT status, with a reported overall survival of 30 months for methylated patients and 19.1 months for unmethylated patients, respectively. Based on these results, a large multicentric Phase III randomized study Cilengitide in Combination with Temozolomide and Radiotherapy in Newly Diagnosed Glioblastoma phase III Randomized clinical trial (CENTRIC study) of more than 500 patients has assessed 
the efficacy and safety of cilengitide in combination with standard treatment versus standard treatment alone in newly diagnosed GBM patients with a methylated MGMT promoter gene. ${ }^{122}$ Unfortunately, the results of the study showed that the addition of cilengitide to the standard treatment of RT and TMZ did not improve overall survival. A similar trial Cilengitide in Patients with newly Diagnosed and Glioblastoma Multiforme and unmethylated MGMT gene promoter (CORE study) is currently evaluating GBM patients with an unmethylated MGMT gene promoter status treated with standard chemoradiation or chemoradiation plus cilengitide, although no results have been reported yet. ${ }^{122}$

\section{Combinations of EGFR inhibitors with radiation}

The EGFR is a transmembrane glycoprotein that constitutes one of four members of the ErbB family of tyrosine kinase receptors. It consists of an extracellular ligand-binding domain, a transmembrane segment, and an intracellular domain with an ATP-binding site and tyrosine kinase activity. EGFR is activated by ligand binding to the extracellular domain, which leads to rapid receptor dimerization and subsequent activation of tyrosine kinase activity in the intracellular domain. This results in the stimulation of downstream signaling effectors including PI3K, Akt, Ras, and mitogen-activated protein kinases, which are involved in cell proliferation, survival, migration, and apoptosis. ${ }^{123}$ EGFR is highly expressed in a variety of solid tumors, including high-grade gliomas. ${ }^{124}$ Approximately $40 \%$ of GBMs are characterized by EGFR gene amplification and overexpression, ${ }^{125,126}$ which promote tumor growth, migration and invasion, ${ }^{127}$ and induce resistance to radiation. ${ }^{128}$ Amplification of the EGFR gene is often associated with a mutation that encodes for a truncated form of the receptor, known as EGFR variant vIII (EGFRvIII), which lacks the extracellular binding domain leading to constitutive activation of tyrosine kinase. ${ }^{125,129}$ Expression of EGFRvIII correlates with poor survival in GBM patients ${ }^{130,131}$ and promotes glioma cell migration, ${ }^{132}$ tumor growth, invasion, survival, ${ }^{133}$ and angiogenesis. ${ }^{134}$ Moreover, it was shown that resistance of GBM cells in vitro toward RT is related to Human Epidermal Receptor (HER1)/ EGFR overexpression. ${ }^{128,135}$ A large number of potentially therapeutic targets have been developed in order to block the EGFR signaling pathways, including monoclonal antibodies cetuximab (Erbitux ${ }^{\circledR}$; Eli Lilly and Company; Bristol-Myers Squibb, New York, NY, USA), and TKIs gefitinib (Iressa ${ }^{\mathrm{TM}}$; AstraZeneca Pharmaceuticals), erlotinib (Tarceva ${ }^{\circledR}$; OSI Pharmaceuticals, Inc, Melville, NY, USA; F Hoffman-La Roche, Ltd, Basel, Switzerland; Genentech, Inc) and lapatinib
(Tykerb $^{\circledR}$; GlaxoSmithKline plc, London, UK). Erlotinib and gefitinib are two structurally related, orally active small molecule reversible TKIs that compete for the ATP-binding site in the intracellular tyrosine kinase domain of EGFR, thereby resulting in the inhibition of downstream signal transduction pathways. ${ }^{136}$ Both targeted drugs have shown clinical activity against several cancer types, and both received approval as a second- or third-line treatment in previously treated advanced NSCLC. ${ }^{137,138}$ Erlotinib has also been approved in combination with gemcitabine for locally advanced, unresectable, or metastatic pancreatic cancer; ${ }^{139}$ however, the use of EGFR inhibitors, erlotinib and gefitinib, as single agents in patients with progressive GBM has shown no significant survival benefit. ${ }^{140,141}$

In vitro and in vivo studies have provided strong evidence for the capacity of EGFR TKIs, erlotinib and gefitinib, to enhance the antitumor activity of ionizing radiation. Published data suggest that EGFR TKIs may enhance radiation responses at several levels, including through cell cycle kinetics, DNA damage repair, apoptosis induction, and the targeting of accelerated cellular repopulation. ${ }^{142-146}$ Moreover, EGFR inhibitors like erlotinib may decrease tumor hypoxia, thereby rendering cells more susceptible to the cytotoxic effects of radiation. Therefore, this strategy has been tested in Phase I/II clinical studies (Table 2).

An initial Phase I trial of erlotinib with standard RT and TMZ treatment in patients with newly diagnosed GBM was performed by the North Central Cancer Treatment Group (NCCTG). ${ }^{147}$ Erlotinib was given orally daily throughout standard RT and TMZ, starting 1 week before the beginning of chemoradiotherapy during the 6-month cycles of adjuvant $\mathrm{TMZ}$, and this regimen was continued until tumor progression. The drug was started at a dose of $100 \mathrm{mg} /$ day and was escalated to $150 \mathrm{mg} /$ day for patients not on EIAEDs $(\mathrm{n}=10)$ and $200 \mathrm{mg}$ /day for patients on EIAEDs $(n=9)$. The MTD was not reached, and only one DLT (stomatitis) was observed in the $100 \mathrm{mg}$ group. At a median follow-up of 52 weeks, the median overall survival rates in the two arms were 51 weeks and 66 weeks, respectively. Another Phase I dose-escalation trial of erlotinib with RT limited to patients aged 3 years to 25 years with newly diagnosed high-grade gliomas was conducted by Broniscer et al. ${ }^{148}$ Erlotinib was administered once daily during and after RT for up to 3 years, starting at $70 \mathrm{mg} / \mathrm{m}^{2}$ to the final dosage of $160 \mathrm{mg} / \mathrm{m}^{2}$. The recommended MTD was $120 \mathrm{mg} / \mathrm{m}^{2}$ per day. Toxicities reported in 23 evaluable patients included one grade 3 diarrhea at $120 \mathrm{mg} / \mathrm{m}^{2}$, one grade 3 serum lipase increase, and one grade 3 rash and pruritus at $160 \mathrm{mg} / \mathrm{m}^{2}$. The 1-year progression-free survival and overall survival were $56 \%$ and $78 \%$, respectively. 
Table 2 Clinical trials of EGFR and mTOR inhibitors in combination with radiotherapy

\begin{tabular}{|c|c|c|c|c|c|c|}
\hline Authors & Reference & Drug & Patients & Tumor & Drug dose & Outcomes \\
\hline \multirow[t]{2}{*}{ Krishnan et al } & 147 & Erlotinib & 19 & $\begin{array}{l}\text { Newly diagnosed } \\
\text { GBM }\end{array}$ & $\begin{array}{l}100 \mathrm{mg} / \text { day to } 150 \mathrm{mg} / \text { day for } \\
\text { patients not on ElAEDs + RT }\end{array}$ & OS: 5 I weeks \\
\hline & & & & & $\begin{array}{l}100 \mathrm{mg} / \text { day to } 200 \mathrm{mg} / \text { day for } \\
\text { patients on EIAEDs + RT }\end{array}$ & OS: 66 weeks \\
\hline Brown et al & 149 & Erlotinib & 97 & $\begin{array}{l}\text { Newly diagnosed } \\
\text { GBM }\end{array}$ & 150 mg/day + RT + TMZ & $\begin{array}{l}\text { PFS: } 7.2 \text { months } \\
\text { OS: } 15.3 \text { months }\end{array}$ \\
\hline Broniscer et al & 148 & Erlotinib & 23 (3-25 years) & $\begin{array}{l}\text { Newly diagnosed } \\
\text { HGGs }\end{array}$ & $70 \mathrm{mg} / \mathrm{m}^{2}$ to $160 \mathrm{mg} / \mathrm{m}^{2}+\mathrm{RT}$ & $\begin{array}{l}\text { PFS-12: } 56 \% \\
\text { OS-12: } 78 \%\end{array}$ \\
\hline Prados et al & 4 & Erlotinib & 65 & $\begin{array}{l}\text { Newly diagnosed } \\
\text { GBM or GS }\end{array}$ & $\begin{array}{l}100 \mathrm{mg} / \text { day to } 200 \mathrm{mg} / \text { day for } \\
\text { patients not on EIAEDs }+\mathrm{RT}+\mathrm{TMZ} \\
200 \mathrm{mg} / \text { day to } 500 \mathrm{mg} / \text { day for } \\
\text { patients on EIAEDs }+\mathrm{RT}+\mathrm{TMZ}\end{array}$ & $\begin{array}{l}\text { PFS: } 8.2 \text { months } \\
\text { OS: } 19.3 \text { months }\end{array}$ \\
\hline Peereboom et al & 3 & Erlotinib & 27 & $\begin{array}{l}\text { Newly diagnosed } \\
\text { GBM }\end{array}$ & $\begin{array}{l}50 \mathrm{mg} / \text { day to } 150 \mathrm{mg} / \text { day }+ \\
\text { RT + TMZ }\end{array}$ & $\begin{array}{l}\text { PFS: } 2.8 \text { months } \\
\text { OS: } 8.6 \text { months }\end{array}$ \\
\hline Schwer et al & 150 & Gefitinib & 15 & Recurrent HGGs & $250 \mathrm{mg} /$ day + FSRS & $\begin{array}{l}\text { PFS: } 7 \text { months } \\
\text { OS: } 10 \text { months }\end{array}$ \\
\hline Geyer et al & $|5|$ & Gefitinib & 33 (3-2I years) & $\begin{array}{l}\text { Newly diagnosed } \\
\text { BSG or STMG }\end{array}$ & $100 \mathrm{mg} / \mathrm{m}^{2}$ to $375 \mathrm{mg} / \mathrm{m}^{2}+\mathrm{RT}$ & $\begin{array}{l}\text { OS-I2: } 48 \% \text { (BSG) } \\
\text { OS- I2: } 28.8 \% \\
\text { (STMG) }\end{array}$ \\
\hline Pollack et al & 152 & Gefitinib & 43 (3-2I years) & $\begin{array}{l}\text { Newly diagnosed } \\
\text { gliomas }\end{array}$ & $250 \mathrm{mg} / \mathrm{m}^{2}+\mathrm{RT}$ & $\begin{array}{l}\text { PFS-12: } 20.9 \% \\
\text { OS-12: } 56.4 \%\end{array}$ \\
\hline Chakravarti et al & 153 & Gefitinib & 147 & $\begin{array}{l}\text { Newly diagnosed } \\
\text { GBM }\end{array}$ & $500 \mathrm{mg} /$ day + RT & $\begin{array}{l}\text { PFS: } 4.9 \text { months } \\
\text { OS: II.I months }\end{array}$ \\
\hline Sarkaria et al & 163 & Temsirolimus & 25 & $\begin{array}{l}\text { Newly diagnosed } \\
\text { GBM }\end{array}$ & $\begin{array}{l}25 \mathrm{mg} / \text { week to } 75 \mathrm{mg} / \text { week + } \\
\text { RT + TMZ }\end{array}$ & OS: I3.3 months \\
\hline Sarkaria et al & 164 & Everolimus & 18 & $\begin{array}{l}\text { Newly diagnosed } \\
\text { GBM }\end{array}$ & $\begin{array}{l}30 \mathrm{mg} / \text { week to } 70 \mathrm{mg} / \text { week + } \\
\text { RT + TMZ }\end{array}$ & SD: I5 patients \\
\hline
\end{tabular}

Abbreviations: EGFR, epidermal growth factor receptor; mTOR, mammalian target of rapamycin; GBM, glioblastoma; EIAED, enzyme-inducing antiepileptic drug; RT, radiotherapy; OS, overall survival; TMZ, temozolomide; PFS, progression-free survival; HGGs, high-grade gliomas; PFS-12, I2-month progression-free survival; OS-12, I2-month overall survival; GS, gliosarcoma; FSRS, fractionated stereotactic radiosurgery; BSG, brainstem glioma; STMG, supratentorial malignant glioma; SD, Stable Disease.

Prados et $a l^{4}$ have evaluated the efficacy of erlotinib combined to standard RT and TMZ treatment in 65 patients with newly diagnosed GBM or gliosarcoma. Erlotinib was administered during RT at a dose of $100 \mathrm{mg} /$ day for patients not on EIAEDs and $200 \mathrm{mg} /$ day for patients on EIAEDs. Two weeks after completion of chemoradiation, therapy was continued with adjuvant TMZ and erlotinib at a dose of $150 \mathrm{mg} /$ day for patients not on EIAEDs, and $300 \mathrm{mg} /$ day for patients on EIAEDs. The dose was escalated $50 \mathrm{mg}$ per day every 2 weeks to a maximum of $200 \mathrm{mg} /$ day or $500 \mathrm{mg} /$ day for either group, respectively. The most common grade 3 to 4 toxicities likely related to erlotinib were diarrhea, rash, and fatigue. Median overall survival and progression-free survival were 19.3 months and 8.2 months, respectively, which compared favorably with two historical Phase II trials of patients with GBM treated with RT and TMZ in association with thalidomide or cis-retinoic acid. ${ }^{97,98}$ Patients with the MGMT gene promoter methylation, as well as patients with either MGMT promoter-methylated tumor and intact phosphatase and tensin homologue (PTEN), a tumor-suppressor protein that inhibits the PI3K signaling pathway, had a significantly longer median survival when compared with patients with unmethylated MGMT (25.5 months versus 14.6 months, $P=0.006$ ).

Brown et $\mathrm{al}^{149}$ have reported the results of a Phase I/II study conducted by the NCCTG (N0177 Study) in 93 patients with newly diagnosed GBM treated with erlotinib at a dose of $150 \mathrm{mg}$ /day combined with standard RT and TMZ. Median progression-free survival and overall survival rates were 7.2 months and 15.3 months, respectively, being not significantly different compared to historical data from the European Organization for Research and Treatment of Cancer, National Cancer Institute of Canada (NCIC) trial conducted by Stupp et al. ${ }^{2}$ Different from the Prados et $\mathrm{al}^{4}$ study, no differences were found in survival rates in patient groups characterized by EGFRvIII plus wild PTEN versus groups without these genotypic features. Moreover, the addition of erlotinib was associated with increased toxicity compared with standard RT and TMZ treatment, with two reported grade 5 nonneutropenic pneumonias. In another Phase II study of patients with newly diagnosed GBM, erlotinib was given from the first day of standard RT and TMZ at a dose of $50 \mathrm{mg}$ /day with escalation by $50 \mathrm{mg} /$ day every 2 weeks to a maximum dose of $150 \mathrm{mg} /$ day, 
until the occurrence of toxicity or disease progression. ${ }^{3}$ Median progression-free survival and overall survival rates were 2.8 months and 8.6 months, respectively. Treatment-related grade 3 or 4 toxicities included thrombocytopenia, anemia, lymphopenia, fatigue, and febrile neutropenia. Three deaths that were attributed to treatment occurred during the study, leading to early closure of the trial - after enrollment of 27 of the 30 planned patients.

Few trials have reported on the combination of gefitinib with RT as first-line treatment in both adult and pediatric patients, or at tumor recurrence (Table 2). A Phase I doseescalation study of 15 patients with recurrent malignant gliomas treated with fractionated stereotactic radiosurgery in combination with gefitinib was performed by Schwer et al. ${ }^{150}$ Gefitinib was administered orally at a dose of $250 \mathrm{mg} /$ day starting 1 week before fractionated stereotactic radiosurgery and continued for up to 1 year, or until disease progression or unacceptable toxicity. The initial dosage of Stereotactic Radio Surgery (SRS) was 18 Gy delivered in three fractions over 3 consecutive days, and subsequent RT doses were 24 Gy, 30 Gy, and 36 Gy. Treatment was well tolerated, and grade $3 / 4$ toxicities were not reported. At a median follow-up of 7 months, the median overall survival and progression-free survival rates were 10 months and 7 months, respectively.

The Pediatric Brain Tumor Consortium initiated a Phase I trial of gefitinib and RT in children with newly diagnosed brainstem gliomas or incompletely resected supratentorial malignant gliomas. ${ }^{151}$ Thirty-three patients aged 3 years to 21 years were included in the study. Gefitinib was started concomitantly to RT. Gefitinib at a starting dose of $100 \mathrm{mg} / \mathrm{m}^{2}$ was administered orally once daily from the first day of RT, and the dose was subsequently escalated to $250 \mathrm{mg} / \mathrm{m}^{2}$ and $375 \mathrm{mg} / \mathrm{m}^{2}$. In the absence of disease progression or DLT, treatment was continued for 1 year. Although systemic toxicities were generally mild-moderate and reversible, there were four cases of symptomatic intratumoral hemorrhage and the trial was prematurely closed. In total, $250 \mathrm{mg} / \mathrm{m}^{2}$ was established as the recommended Phase II dose. The 1-year survival and progression-free survival rates were $48 \%$ and $16.1 \%$ for patients with brainstem glioma, and $28.8 \%$ and $15.4 \%$, for patients with supratentorial glioma, respectively. In the subsequent Phase II trial, 43 children were enrolled and received gefitinib at a dose of $250 \mathrm{mg} / \mathrm{m}^{2} /$ day in combination with RT. ${ }^{152}$ One-year progression-free survival and overall survival rates were $20.9 \%$ and $56.4 \%$, respectively. The most frequent toxicity was lymphopenia. Three patients experienced intratumoral hemorrhage, which was symptomatic in two cases.
More recently, the Radiation Therapy Oncology Group conducted a Phase I/II study to evaluate the safety and efficacy of gefitinib administered with RT in patients with newly diagnosed GBM. ${ }^{153}$ In the Phase I part of the trial, gefitinib was given at $250 \mathrm{mg}$ daily and escalated to a maximum dose of $750 \mathrm{mg}$ for patients on EIAEDs $(\mathrm{n}=18)$ or $500 \mathrm{mg}$ for patients not on EIAEDs $(n=13)$. After the completion of RT, gefitinib was continued as a single-agent for 18 months, or until disease progression or unacceptable toxicity. The MTD was established to be $750 \mathrm{mg}$ for patients on EIAEDs and $500 \mathrm{mg}$ for patients not on EIAEDs. The most frequent reported toxicities were dermatologic, gastrointestinal, and fatigue. Therefore, 147 patients were enrolled to the Phase II component of the study that included only patients not on EIAEDs treated with gefitinib at $500 \mathrm{mg}$ in combination with RT. Treatment was well tolerated with grade 3/4 rash, grade 3/4 gastrointestinal toxicity, grade 3/4 liver function test abnormalities, and grade 3/4 cardiovascular complications being the most common adverse events. However, despite a relatively good toxicity profile, overall survival was not significantly improved by the addition of gefitinib to RT, as compared to historical controls treated with RT alone (11.5 months versus 11 months).

\section{Combination of $\mathbf{m T O R}$ inhibitors with RT}

The mTOR complex is a serine-threonine kinase composed of two proteins, mTOR complex 1 and 2 (mTORC1 and mTORC2), that acts as a downstream effector of the PI3K and Akt/PKB (Protein Kinase B) signaling pathway. ${ }^{154}$ Specifically, mTOR is regulated through activation of the PI3K/ Akt cascade and promotes cell growth and proliferation through phosphorylation and inactivation of the translational regulator eukaryotic initiation factor 4E-binding protein, as well as through phosphorylation and activation of the $70 \mathrm{kd}$ S6 (S6K1) ribosomal protein kinase. ${ }^{155}$ An upstream negative regulator of this pathway is the tumor suppressor PTEN, which is commonly mutated in $20 \%-40 \%$ of GBMs ${ }^{156}$ Thus, targeting the mTOR complex may represent an attractive therapeutic approach for GBM, and synthetic analogs of rapamycin (sirolimus), including temsirolimus (Torisel ${ }^{\circledR}$; Wyeth Pharmaceuticals, Madison, NJ, USA), everolimus (Afinitor $^{\circledR}$; Novartis Vaccines and Diagnostics AG, Basel, Switzerland), and ridaforolimus (MK-8669; AP23573; Merck KgaA; ARIAD Pharmaceuticals, Inc, Cambridge, MA, USA) are currently being tested in GBM. Temsirolimus and everolimus have received US FDA and European Medicines Agency approval for the treatment of advanced renal cell carcinoma, 
as well as for treatment of patients with subependymal giant cell astrocytoma, tuberous sclerosis, advanced breast cancer, and pancreatic neuroendocrine tumors (everolimus). ${ }^{157,158}$

Preclinical studies have shown that mTOR inhibitors can enhance tumor response to radiation by affecting both tumor vasculature and tumor cell viability through different mechanisms. The addition of everolimus to RT sensitizes GBM cell lines to radiation by decreasing cell survival through the activation of apoptosis, the induction of cell cycle arrest, ${ }^{159,160}$ and the upregulation of autophagy. ${ }^{161}$ In addition, combined treatment decreases tumor vessel density and blood flow in vivo. ${ }^{162}$ In U87 GBM xenografts, the addition of rapamycin to RT significantly enhances tumor growth control compared to either radiation or rapamycin alone. ${ }^{159}$

Two Phase I trials have investigated the safety and efficacy of mTOR inhibitors in combination with RT in GBM (Table 2). NCCTG conducted a Phase I dose-escalation trial of temsirolimus with RT and TMZ in patients with newly diagnosed GBM. ${ }^{163}$ Temsirolimus was administered intravenously weekly 1 week before chemoradiation and continued with adjuvant TMZ for up to six cycles. The dose started at $25 \mathrm{mg} /$ week and was escalated to the final dosage of $75 \mathrm{mg} /$ week. Among the first twelve patients enrolled, six patients developed an infection during adjuvant TMZ, and three of these patients died. Subsequently, 13 additional patients received temsirolimus only concomitantly to RT and TMZ. DLTs occurred to doses of $75 \mathrm{mg} /$ week in two out of six patients during RT and included dysgeusia, hypercholesterolemia, hypertriglyceridemia, thrombocytopenia, thrombosis, and pulmonary embolism. The recommended dose was $50 \mathrm{mg} /$ week. At a median follow-up of 10.2 months, stable disease was reported in 24 patients and progressive disease was reported in one patient. ${ }^{163}$

The NCCTG also performed a Phase I trial to evaluate the safety and tolerability of everolimus with standard RT and TMZ treatment in 18 patients with newly diagnosed GBM. ${ }^{164}$ Everolimus was administered orally once per week beginning 1 week before RT. The starting dose was $30 \mathrm{mg} /$ week with subsequent escalations to $50 \mathrm{mg} /$ week and $70 \mathrm{mg} /$ week in cohorts of six patients. After completion of concomitant treatment, everolimus was given weekly in combination with TMZ for 6 months, or until disease progression or toxicity. Treatment-related DLTs were one instance of grade 3 fatigue at doses of $30 \mathrm{mg} /$ week, one grade 4 myelotoxicity at doses of $50 \mathrm{mg} /$ week, and one grade 4 liver dysfunction at doses of $70 \mathrm{mg} /$ week. Consequently, a dose of $70 \mathrm{mg} /$ weekly was recommended for Phase II studies. A partial response was reported in one patient and stable disease was reported in 15 patients. Given the small number of patients in both trials, no conclusions can be drawn on safety and efficacy of mTOR inhibitors combined with RT, and further investigation is warranted.

\section{Conclusion}

An increasing body of preclinical data show that inhibition of EGFR-, VEGFR-, integrin-, and mTOR-mediated signaling may enhance the effect of radiation through several mechanisms, including activation of apoptosis, induction of cell cycle arrest, inhibition of angiogenesis, and by improving tumor oxygenation. Several trials have assessed the efficacy of combining targeted agents with radiation in newly diagnosed and recurrent high-grade gliomas; however, despite the strong rationale for their use in clinical trials, most studies have shown very modest results. Currently, only the use of bevacizumab in combination with RT plus TMZ has been associated with improved progression-free survival and quality of life in patients with newly diagnosed GBM in a large randomized study, although without significant survival benefit. In contrast, Phase II/III trials evaluating the addition of single agents targeting angiogenesis, integrins, and EGFR-signaling pathways showed no survival advantages when compared to the standard treatment of TMZ plus RT alone; however, in a study testing EGFR TKI erlotinib in combination with RT and TMZ, a subset of patients with MGMT promoter methylation and PTEN positivity showed significantly longer survival. ${ }^{4}$

The negative results reported in the majority of published clinical studies may be explained, at least in part, by this single-target approach, which may be somewhat limited by such factors as tumor heterogeneity and genetic instability. Heterogeneity of the GBM cell population, which includes expression of cell surface receptors, as well as proliferative and angiogenic potential, might be attributed to morphological and epigenetic plasticity, but there is also evidence for the coexistence of genetically divergent tumor cell clones within tumors. So far, if multiple oncogenic processes are active in distinct tumor subpopulations, single-target therapies may provide limited effects. Furthermore, GBM cells may exhibit significant genetic instability, possibly leading to resistance of single-targeted agents by switching to alternative molecular pathways that may influence radiation resistance. This complex interaction between tumor-specific signaling and radiation response provides a rationale for the use of multiple single-targeted therapies that can simultaneously inhibit a variety of molecular pathways, including growth 
factor receptor signaling pathways, DNA damage repair processes, and angiogenesis. A better understanding of the multiple mechanisms underlying radiation response and resistance in GBM will help to select patients based on molecular biomarkers, who may benefit from multitarget therapy regimens in clinical trials.

\section{Disclosure}

The authors report no conflicts of interest in this work.

\section{References}

1. Deorah S, Lynch CF, Sibenaller ZA, Ryken TC. Trends in brain cancer incidence and survival in the United States: Surveillance, Epidemiology, and End Results Program, 1973 to 2001. Neurosurg Focus. 2006;20(4):E1.

2. Stupp R, Mason WP, van den Bent MJ, et al; European Organisation for Research and Treatment of Cancer Brain Tumor and Radiotherapy Groups; National Cancer Institute of Canada Clinical Trials Group. Radiotherapy plus concomitant and adjuvant temozolomide for glioblastoma. N Engl J Med. 2005;352(10):987-996.

3. Peereboom DM, Shepard DR, Ahluwalia MS, et al. Phase II trial of erlotinib with temozolomide and radiation in patients with newly diagnosed glioblastoma multiforme. J Neurooncol. 2010;98(1):93-99.

4. Prados MD, Chang SM, Butowski N, et al. Phase II study of erlotinib plus temozolomide during and after radiation therapy in patients with newly diagnosed glioblastoma multiforme or gliosarcoma. J Clin Oncol. 2009;27(4):579-584.

5. Uhm JH, Ballman KV, Wu W, et al. Phase II evaluation of gefitinib in patients with newly diagnosed Grade 4 astrocytoma: Mayo/North Central Cancer Treatment Group Study N0074. Int J Radiat Oncol Biol Phys. 2011;80(2):347-353.

6. Franceschi E, Cavallo G, Lonardi S, et al. Gefitinib in patients with progressive high-grade gliomas: a multicentre phase II study by Gruppo Italiano Cooperativo di Neuro-Oncologia (GICNO). Br J Cancer. 2007;96(7):1047-1051.

7. Nabors LB, Supko JG, Rosenfeld M, et al; New Approaches to Brain Tumor Therapy (NABTT) CNS Consortium. Phase I trial of sorafenib in patients with recurrent or progressive malignant glioma. Neuro-oncology. 2011;13(12):1324-1330.

8. Fields EC, Damek D, Gaspar LE, et al. Phase I dose escalation trial of vandetanib with fractionated radiosurgery in patients with recurrent malignant gliomas. Int J Radiat Oncol Biol Phys. 2012;82(1):51-57.

9. Gerstner ER, Eichler AF, Plotkin SR, et al. Phase I trial with biomarker studies of vatalanib (PTK787) in patients with newly diagnosed glioblastoma treated with enzyme inducing anti-epileptic drugs and standard radiation and temozolomide. $J$ Neurooncol. 2011;103(2):325-332.

10. Vredenburgh JJ, Desjardins A, Reardon DA, et al. The addition of bevacizumab to standard radiation therapy and temozolomide followed by bevacizumab, temozolomide, and irinotecan for newly diagnosed glioblastoma. Clin Cancer Res. 2011;17(12):4119-4124.

11. Lai A, Tran A, Nghiemphu PL, et al. Phase II study of bevacizumab plus temozolomide during and after radiation therapy for patients with newly diagnosed glioblastoma multiforme. J Clin Oncol. 2011;29(2): 142-148.

12. Galanis E, Buckner JC, Maurer MJ, et al; North Central Cancer Treatment Group. Phase II trial of temsirolimus (CCI-779) in recurrent glioblastoma multiforme: a North Central Cancer Treatment Group Study. J Clin Oncol. 2005;23(23):5294-5304.

13. Stupp R, Hegi ME, Neyns B, et al. Phase I/IIa study of cilengitide and temozolomide with concomitant radiotherapy followed by cilengitide and temozolomide maintenance therapy in patients with newly diagnosed glioblastoma. J Clin Oncol. 2010;28(16):2712-2718.
14. Nabors LB, Mikkelsen T, Hegi ME, et al; New Approaches to Brain Tumor Therapy (NABTT) Central Nervous System Consortium. A safety run-in and randomized phase 2 study of cilengitide combined with chemoradiation for newly diagnosed glioblastoma (NABTT 0306). Cancer. 2012;118(22):5601-5607.

15. Minniti G, Muni R, Lanzetta G, et al; chemotherapy for glioblastoma: current treatment and future perspectives for cytotoxic and targeted agents. Anticancer Res. 2009;29(12):5171-5184.

16. Dorsey K, Agulnik M. Promising new molecular targeted therapies in head and neck cancer. Drugs. 2013;73(4):315-325.

17. Petrosyan F, Daw H, Haddad A, Spiro T. Targeted therapy for lung cancer. Anticancer Drugs. 2012;23(10):1016-1021.

18. Gorski DH, Beckett MA, Jaskowiak NT, et al. Blockage of the vascular endothelial growth factor stress response increases the antitumor effects of ionizing radiation. Cancer Res. 1999;59(14):3374-3378.

19. Geng L, Donnelly E, McMahon G, et al. Inhibition of vascular endothelial growth factor receptor signaling leads to reversal of tumor resistance to radiotherapy. Cancer Res. 2001;61(6):2413-2419.

20. Gupta VK, Jaskowiak NT, Beckett MA, et al. Vascular endothelial growth factor enhances endothelial cell survival and tumor radioresistance. Cancer J. 2002;8(1):47-54.

21. Hovinga KE, Stalpers LJ, van Bree C, et al. Radiation-enhanced vascular endothelial growth factor (VEGF) secretion in glioblastoma multiforme cell lines - a clue to radioresistance? J Neurooncol. 2005;74(2) 99-103.

22. Wachsberger PR, Burd R, Cardi C, et al. VEGF trap in combination with radiotherapy improves tumor control in $\mathrm{u} 87$ glioblastoma. Int $J$ Radiat Oncol Biol Phys. 2007;67(5):1526-1537.

23. Kil WJ, Tofilon PJ, Camphausen K. Post-radiation increase in VEGF enhances glioma cell motility in vitro. Radiat Oncol. 2012;7:25.

24. Birner P, Piribauer M, Fischer I, et al. Vascular patterns in glioblastoma influence clinical outcome and associate with variable expression of angiogenic proteins: evidence for distinct angiogenic subtypes. Brain Pathol. 2003;13(2):133-143.

25. Presta LG, Chen H, O'Connor SJ, et al. Humanization of an antivascular endothelial growth factor monoclonal antibody for the therapy of solid tumors and other disorders. Cancer Res. 1997;57(20): 4593-4599.

26. Gerber HP, Ferrara N. Pharmacology and pharmacodynamics of bevacizumab as monotherapy or in combination with cytotoxic therapy in preclinical studies. Cancer Res. 2005;65(3):671-680.

27. Yuan F, Chen Y, Dellian M, Safabakhsh N, Ferrara N, Jain RK Time-dependent vascular regression and permeability changes in established human tumor xenografts induced by an anti-vascular endothelial growth factor/vascular permeability factor antibody. Proc Natl Acad Sci U S A. 1996;93(25):14765-14770.

28. Borgström P, Hillan KJ, Sriramarao P, Ferrara N. Complete inhibition of angiogenesis and growth of microtumors by anti-vascular endothelial growth factor neutralizing antibody: novel concepts of angiostatic therapy from intravital videomicroscopy. Cancer Res. 1996;56(17): 4032-4039.

29. Willett CG, Boucher Y, di Tomaso E, et al. Direct evidence that the VEGF-specific antibody bevacizumab has antivascular effects in human rectal cancer. Nat Med. 2004;10(2):145-147.

30. Hurwitz H, Fehrenbacher L, Novotny W, et al. Bevacizumab plus irinotecan, fluorouracil, and leucovorin for metastatic colorectal cancer. N Engl J Med. 2004;350(23):2335-2342.

31. Sandler A, Gray R, Perry MC, et al. Paclitaxel-carboplatin alone or with bevacizumab for non-small-cell lung cancer. $N$ Engl J Med. 2006;355(24):2542-2550.

32. Escudier B, Pluzanska A, Koralewski P, et al; AVOREN Trial investigators. Bevacizumab plus interferon alfa-2a for treatment of metastatic renal cell carcinoma: a randomised, double-blind phase III trial. Lancet. 2007;370(9605):2103-2111.

33. Friedman HS, Prados MD, Wen PY, et al. Bevacizumab alone and in combination with irinotecan in recurrent glioblastoma. J Clin Oncol. 2009;27(28):4733-4740. 
34. Kreisl TN, Kim L, Moore K, et al. Phase II trial of single-agent bevacizumab followed by bevacizumab plus irinotecan at tumor progression in recurrent glioblastoma. J Clin Oncol. 2009;27(5): $740-745$.

35. Winkler F, Kozin SV, Tong RT, et al. Kinetics of vascular normalization by VEGFR2 blockade governs brain tumor response to radiation: role of oxygenation, angiopoietin-1, and matrix metalloproteinases. Cancer Cell. 2004;6(6):553-563.

36. Hoang T, Huang S, Armstrong E, Eickhoff JC, Harari PM. Enhancement of radiation response with bevacizumab. $J$ Exp Clin Cancer Res. 2012;31:37.

37. Lee CG, Heijn M, di Tomaso E, et al. Anti-vascular endothelial growth factor treatment augments tumor radiation response under normoxic or hypoxic conditions. Cancer Res. 2000;60(19):5565-5570.

38. Dings RP, Loren $\mathrm{M}$, Heun $\mathrm{H}$, et al. Scheduling of radiation with angiogenesis inhibitors anginex and Avastin improves therapeutic outcome via vessel normalization. Clin Cancer Res. 2007;13(11):3395-3402.

39. McGee MC, Hamner JB, Williams RF, et al. Improved intratumoral oxygenation through vascular normalization increases glioma sensitivity to ionizing radiation. Int J Radiat Oncol Biol Phys. 2010;76(5): $1537-1545$

40. Narayana A, Golfinos JG, Fischer I, et al. Feasibility of using bevacizumab with radiation therapy and temozolomide in newly diagnosed high-grade glioma. Int J Radiat Oncol Biol Phys. 2008;72(2): 383-389.

41. Narayana A, Gruber D, Kunnakkat S, et al. A clinical trial of bevacizumab, temozolomide, and radiation for newly diagnosed glioblastoma. J Neurosurg. 2012;116(2):341-345.

42. Lai A, Filka E, McGibbon B, et al. Phase II pilot study of bevacizumab in combination with temozolomide and regional radiation therapy for up-front treatment of patients with newly diagnosed glioblastoma multiforme: interim analysis of safety and tolerability. Int $J$ Radiat Oncol Biol Phys. 2008;71(5):1372-1380.

43. Vredenburgh JJ, Desjardins A, Kirkpatrick JP, et al. Addition of bevacizumab to standard radiation therapy and daily temozolomide is associated with minimal toxicity in newly diagnosed glioblastoma multiforme. Int J Radiat Oncol Biol Phys. 2012;82(1):58-66.

44. Hainsworth JD, Shih KC, Shepard GC, Tillinghast GW, Brinker BT, Spigel DR. Phase II study of concurrent radiation therapy, temozolomide, and bevacizumab followed by bevacizumab/everolimus as first-line treatment for patients with glioblastoma. Clin Adv Hematol Oncol. 2012;10(4):240-246.

45. Chinot OL, de La Motte Rouge T, Moore N, et al. AVAglio: Phase 3 trial of bevacizumab plus temozolomide and radiotherapy in newly diagnosed glioblastoma multiforme. Adv Ther. 2011;28(4):334-340.

46. Gutin PH, Iwamoto FM, Beal K, et al. Safety and efficacy of bevacizumab with hypofractionated stereotactic irradiation for recurrent malignant gliomas. Int J Radiat Oncol Biol Phys. 2009;75(1):156-163.

47. Shapiro LQ, Beal K, Goenka A, et al. Patterns of failure after concurrent bevacizumab and hypofractionated stereotactic radiation therapy for recurrent high-grade glioma. Int J Radiat Oncol Biol Phys. 2013;85(3):636-642.

48. Niyazi M, Ganswindt U, Schwarz SB, et al. Irradiation and bevacizumab in high-grade glioma retreatment settings. Int J Radiat Oncol Biol Phys. 2012;82(1):67-76.

49. Hundsberger T, Brügge D, Putora PM, Weder P, Weber J, Plasswilm L. Re-irradiation with and without bevacizumab as salvage therapy for recurrent or progressive high-grade gliomas. J Neurooncol. 2013;112(1):133-139.

50. Hennequin LF, Stokes ES, Thomas AP, et al. Novel 4-anilinoquinazolines with C-7 basic side chains: design and structure activity relationship of a series of potent, orally active, VEGF receptor tyrosine kinase inhibitors. J Med Chem. 2002;45(6):1300-1312.

51. Ciardiello F, Caputo R, Damiano V, et al. Antitumor effects of ZD6474, a small molecule vascular endothelial growth factor receptor tyrosine kinase inhibitor, with additional activity against epidermal growth factor receptor tyrosine kinase. Clin Cancer Res. 2003;9(4):1546-1556.
52. Brave SR, Odedra R, James NH, et al. Vandetanib inhibits both VEGFR-2 and EGFR signalling at clinically relevant drug levels in preclinical models of human cancer. Int J Oncol. 2011;39(1):271-278.

53. Leboulleux S, Bastholt L, Krause T, et al. Vandetanib in locally advanced or metastatic differentiated thyroid cancer: a randomised, double-blind, phase 2 trial. Lancet Oncol. 2012;13(9):897-905.

54. Meyerhardt JA, Ancukiewicz M, Abrams TA, et al. Phase I study of cetuximab, irinotecan, and vandetanib (ZD6474) as therapy for patients with previously treated metastastic colorectal cancer. PLoS One. 2012;7(6):e38231.

55. Lee JS, Hirsh V, Park K, et al. Vandetanib Versus placebo in patients with advanced non-small-cell lung cancer after prior therapy with an epidermal growth factor receptor tyrosine kinase inhibitor: a randomized, double-blind phase III trial (ZEPHYR). J Clin Oncol. 2012;30(10): 1114-1121.

56. Hsu C, Yang TS, Huo TI, et al. Vandetanib in patients with inoperable hepatocellular carcinoma: a phase II, randomized, double-blind, placebocontrolled study. J Hepatol. 2012;56(5):1097-1103.

57. Thornton K, Kim G, Maher ve, et al. Vandetanib for the treatment of sympomatic or progressive medullary thyroid cancer in patients with unresectable locally advanced or metastatic disease: U.S. Food and Drug administration drug approval cemicar cancer Res. 2012; 18(14):3722-3730.

58. Ansiaux R, Dewever J, Grégoire V, Feron O, Jordan BF, Gallez B. Decrease in tumor cell oxygen consumption after treatment with vandetanib (ZACTIMA; ZD6474) and its effect on response to radiotherapy. Radiat Res. 2009;172(5):584-591.

59. Damiano V, Melisi D, Bianco C, et al. Cooperative antitumor effect of multitargeted kinase inhibitor ZD6474 and ionizing radiation in glioblastoma. Clin Cancer Res. 2005;11(15):5639-5644.

60. Sandström M, Johansson M, Bergström P, Bergenheim AT, Henriksson R. Effects of the VEGFR inhibitor ZD6474 in combination with radiotherapy and temozolomide in an orthotopic glioma model. $J$ Neurooncol. 2008;88(1):1-9.

61. Gustafson DL, Frederick B, Merz AL, Raben D. Dose scheduling of the dual VEGFR and EGFR tyrosine kinase inhibitor vandetanib (ZD6474, Zactima) in combination with radiotherapy in EGFR-positive and EGFR-null human head and neck tumor xenografts. Cancer Chemother Pharmacol. 2008;61(2):179-188.

62. Williams KJ, Telfer BA, Brave S, et al. ZD6474, a potent inhibitor of vascular endothelial growth factor signaling, combined with radiotherapy: schedule-dependent enhancement of antitumor activity. Clin Cancer Res. 2004;10(24):8587-8593.

63. Siemann DW, Horsman MR. Targeting the tumor vasculature: a strategy to improve radiation therapy. Expert Rev Anticancer Ther. 2004;4(2):321-327.

64. Brazelle WD, Shi W, Siemann DW. VEGF-associated tyrosine kinase inhibition increases the tumor response to single and fractionated dose radiotherapy. Int J Radiat Oncol Biol Phys. 2006;65(3):836-841.

65. Drappatz J, Norden AD, Wong ET, et al. Phase I study of vandetanib with radiotherapy and temozolomide for newly diagnosed glioblastoma. Int J Radiat Oncol Biol Phys. 2010;78(1):85-90.

66. Broniscer A, Baker JN, Tagen M, et al. Phase I study of vandetanib during and after radiotherapy in children with diffuse intrinsic pontine glioma. J Clin Oncol. 2010;28(31):4762-4768.

67. Wood JM, Bold G, Buchdunger E, et al. PTK787/ZK222584, a novel and potent inhibitor of vascular endothelial growth factor receptor tyrosine kinases, impairs vascular endothelial growth factor-induced responses and tumor growth after oral administration. Cancer Res. 2000;60(8):2178-2189.

68. Erber R, Thurnher A, Katsen AD, et al. Combined inhibition of VEGF and PDGF signaling enforces tumor vessel regression by interfering with pericyte-mediated endothelial cell survival mechanisms. FASEB J. 2004;18(2):338-340.

69. Hasumi Y, Kłosowska-Wardega A, Furuhashi M, Ostman A, Heldin $\mathrm{CH}$, Hellberg C. Identification of a subset of pericytes that respond to combination therapy targeting PDGF and VEGF signaling. Int J Cancer. 2007;121(12):2606-2614. 
70. Hess C, Vuong V, Hegyi I, et al. Effect of VEGF receptor inhibitor PTK787/ZK222584 [correction of ZK222548] combined with ionizing radiation on endothelial cells and tumour growth. $\mathrm{Br} J$ Cancer. 2001;85(12):2010-2016.

71. Zips D, Krause M, Hessel F, et al. Experimental study on different combination schedules of VEGF-receptor inhibitor PTK787/ ZK222584 and fractionated irradiation. Anticancer Res. 2003;23(5A): 3869-3876.

72. Zips D, Eicheler W, Geyer P, et al. Enhanced susceptibility of irradiated tumor vessels to vascular endothelial growth factor receptor tyrosine kinase inhibition. Cancer Res. 2005;65(12):5374-5379.

73. Brandes AA, Stupp R, Hau P, et al. EORTC study 26041-22041: phase I/II study on concomitant and adjuvant temozolomide (TMZ) and radiotherapy (RT) with PTK787/ZK222584 (PTK/ZK) in newly diagnosed glioblastoma. Eur J Cancer. 2010;46(2):348-354.

74. Hecht JR, Trarbach T, Hainsworth JD, et al. Randomized, placebo-controlled, phase III study of first-line oxaliplatin-based chemotherapy plus PTK787/ZK222584, an oral vascular endothelial growth factor receptor inhibitor, in patients with metastatic colorectal adenocarcinoma. J Clin Oncol. 2011;29(15):1997-2003.

75. Van Cutsem E, Bajetta E, Valle J, et al. Randomized, placebo-controlled, phase III study of oxaliplatin, fluorouracil, and leucovorin with or without PTK787/ZK222584 in patients with previously treated metastatic colorectal adenocarcinoma. J Clin Oncol. 2011;29(15):2004-2010.

76. Adnane L, Trail PA, Taylor I, Wilhelm SM. Sorafenib (BAY 43-9006, Nexavar), a dual-action inhibitor that targets RAF/MEK/ERK pathway in tumor cells and tyrosine kinases VEGFR/PDGFR in tumor vasculature. Meth Enzymol. 2006;407:597-612.

77. Wilhelm SM, Adnane L, Newell P, Villanueva A, Llovet JM, Lynch M. Preclinical overview of sorafenib, a multikinase inhibitor that targets both Raf and VEGF and PDGF receptor tyrosine kinase signaling. Mol Cancer Ther. 2008;7(10):3129-3140.

78. Llovet JM, Ricci S, Mazzaferro V, et al; SHARP Investigators Study Group. Sorafenib in advanced hepatocellular carcinoma. $N$ Engl J Med. 2008;359(4):378-390.

79. Escudier B, Eisen T, Stadler WM, et al; TARGET Study Group. Sorafenib in advanced clear-cell renal-cell carcinoma. $N$ Engl J Med. 2007;356(2):125-134.

80. Siegelin MD, Raskett CM, Gilbert CA, Ross AH, Altieri DC. Sorafenib exerts anti-glioma activity in vitro and in vivo. Neurosci Lett. 2010;478(3):165-170.

81. Yang F, Brown C, Buettner R, et al. Sorafenib induces growth arrest and apoptosis of human glioblastoma cells through the dephosphorylation of signal transducers and activators of transcription 3. Mol Cancer Ther. 2010;9(4):953-962.

82. Carra E, Barbieri F, Marubbi D, et al. Sorafenib selectively depletes human glioblastoma tumor-initiating cells from primary cultures. Cell Cycle. 2013;12(3):491-500.

83. Den RB, Kamrava M, Sheng Z, et al. A phase I study of the combination of sorafenib with temozolomide and radiation therapy for the treatment of primary and recurrent high-grade gliomas. Int J Radiat Oncol Biol Phys. 2013;85(2):321-328.

84. Hug H, Sarre TF. Protein kinase C isoenzymes: divergence in signal transduction? Biochem J. 1993;291(Pt 2):329-343.

85. Musashi M, Ota S, Shiroshita N. The role of protein kinase C isoforms in cell proliferation and apoptosis. Int J Hematol. 2000;72(1):12-19.

86. Podar K, Tai YT, Davies FE, et al. Vascular endothelial growth factor triggers signaling cascades mediating multiple myeloma cell growth and migration. Blood. 2001;98(2):428-435.

87. Yoshiji H, Kuriyama S, Ways DK, et al. Protein kinase C lies on the signaling pathway for vascular endothelial growth factor-mediated tumor development and angiogenesis. Cancer Res. 1999;59(17): 4413-4418.

88. Goekjian PG, Jirousek MR. Protein kinase C inhibitors as novel anticancer drugs. Expert Opin Investig Drugs. 2001;10(12):2117-2140.

89. Teicher BA, Alvarez E, Menon K, et al. Antiangiogenic effects of a protein kinase Cbeta-selective small molecule. Cancer Chemother Pharmacol. 2002;49(1):69-77.
90. Keyes KA, Mann L, Sherman M, et al. LY317615 decreases plasma VEGF levels in human tumor xenograft-bearing mice. Cancer Chemother Pharmacol. 2004;53(2):133-140.

91. Graff JR, McNulty AM, Hanna KR, et al. The protein kinase Cbeta-selective inhibitor, Enzastaurin (LY317615.HCl), suppresses signaling through the AKT pathway, induces apoptosis, and suppresses growth of human colon cancer and glioblastoma xenografts. Cancer Res. 2005;65(16):7462-7469.

92. Spalding AC, Zeitlin BD, Wilder-Romans K, et al. Enzastaurin, an inhibitor of PKCbeta, enhances antiangiogenic effects and cytotoxicity of radiation against endothelial cells. Transl Oncol. 2008;1(4):195-201.

93. Willey CD, Xiao D, Tu T, et al. Enzastaurin (LY317615), a protein kinase $\mathrm{C}$ beta selective inhibitor, enhances antiangiogenic effect of radiation. Int J Radiat Oncol Biol Phys. 2010;77(5):1518-1526.

94. Tabatabai G, Frank B, Wick A, et al. Synergistic antiglioma activity of radiotherapy and enzastaurin. Ann Neurol. 2007;61(2):153-161.

95. Butowski N, Chang SM, Lamborn KR, et al. Enzastaurin plus temozolomide with radiation therapy in glioblastoma multiforme: a phase I study. Neuro-oncology. 2010;12(6):608-613.

96. Butowski N, Chang SM, Lamborn KR, et al. Phase II and pharmacogenomics study of enzastaurin plus temozolomide during and following radiation therapy in patients with newly diagnosed glioblastoma multiforme and gliosarcoma. Neuro-oncology. 2011;13(12):1331-1338.

97. Chang SM, Lamborn KR, Malec M, et al. Phase II study of temozolomide and thalidomide with radiation therapy for newly diagnosed glioblastoma multiforme. Int J Radiat Oncol Biol Phys. 2004;60(2): 353-357.

98. Butowski N, Prados MD, Lamborn KR, et al. A phase II study of concurrent temozolomide and cis-retinoic acid with radiation for adult patients with newly diagnosed supratentorial glioblastoma. Int J Radiat Oncol Biol Phys. 2005;61(5):1454-1459.

99. Gingras MC, Roussel E, Bruner JM, Branch CD, Moser RP. Comparison of cell adhesion molecule expression between glioblastoma multiforme and autologous normal brain tissue. J Neuroimmunol. 1995;57(1-2):143-153.

100. Gladson CL. Expression of integrin alpha v beta 3 in small blood vessels of glioblastoma tumors. J Neuropathol Exp Neurol. 1996;55(11):1143-1149.

101. Hood JD, Cheresh DA. Role of integrins in cell invasion and migration. Nat Rev Cancer. 2002;2(2):91-100.

102. Takada Y, Ye X, Simon S. The integrins. Genome Biol. 2007;8(5):215.

103. Huveneers S, Truong H, Danen HJ. Integrins: signaling, disease, and therapy. Int J Radiat Biol. 2007;83(11-12):743-751.

104. Desgrosellier JS, Cheresh DA. Integrins in cancer: biological implications and therapeutic opportunities. Nat Rev Cancer. 2010;10(1):9-22.

105. Abdollahi A, Griggs DW, Zieher H, et al. Inhibition of alpha(v) beta3 integrin survival signaling enhances antiangiogenic and antitumor effects of radiotherapy. Clin Cancer Res. 2005;11(17):6270-6279.

106. Ning S, Chen Z, Dirks A, et al. Targeting integrins and PI3K/Aktmediated signal transduction pathways enhances radiation-induced anti-angiogenesis. Radiat Res. 2007;168(1):125-133.

107. Monferran S, Skuli N, Delmas C, et al. Alphavbeta3 and alphavbeta5 integrins control glioma cell response to ionising radiation through ILK and RhoB. Int J Cancer. 2008;123(2):357-364.

108. Ning S, Nemeth JA, Hanson RL, Forsythe K, Knox SJ. Anti-integrin monoclonal antibody CNTO 95 enhances the therapeutic efficacy of fractionated radiation therapy in vivo. Mol Cancer Ther. 2008;7(6): $1569-1578$.

109. Ning S, Tian J, Marshall DJ, Knox SJ. Anti-alphav integrin monoclonal antibody intetumumab enhances the efficacy of radiation therapy and reduces metastasis of human cancer xenografts in nude rats. Cancer Res. 2010;70(19):7591-7599.

110. Goodman SL, Hölzemann G, Sulyok GA, Kessler H. Nanomolar small molecule inhibitors for alphav(beta)6, alphav(beta)5, and alphav(beta)3 integrins. J Med Chem. 2002;45(5):1045-1051. 
111. Belvisi L, Riccioni T, Marcellini M, et al. Biological and molecular properties of a new alpha(v)beta3/alpha(v)beta5 integrin antagonist. Mol Cancer Ther. 2005;4(11):1670-1680.

112. Dechantsreiter MA, Planker E, Mathä B, et al. N-Methylated cyclic RGD peptides as highly active and selective alpha(V)beta(3) integrin antagonists. J Med Chem. 1999;42(16):3033-3040.

113. Alva A, Slovin S, Daignault S, et al. Phase II study of cilengitide (EMD 121974, NSC 707544) in patients with non-metastatic castration resistant prostate cancer, NCI-6735. A study by the DOD/ PCF prostate cancer clinical trials consortium. Invest New Drugs. 2012;30(2):749-757.

114. Friess H, Langrehr JM, Oettle H, et al. A randomized multi-center phase II trial of the angiogenesis inhibitor Cilengitide (EMD 121974) and gemcitabine compared with gemcitabine alone in advanced unresectable pancreatic cancer. BMC Cancer. 2006;6:285.

115. Vermorken JB, Guigay J, Mesia R, et al. Phase I/II trial of cilengitide with cetuximab, cisplatin and 5-fluorouracil in recurrent and/or metastatic squamous cell cancer of the head and neck: findings of the phase I part. Br J Cancer. 2011;104(11):1691-1696.

116. Nabors LB, Mikkelsen T, Rosenfeld SS, et al. Phase I and correlative biology study of cilengitide in patients with recurrent malignant glioma. J Clin Oncol. 2007;25(13):1651-1657.

117. MacDonald TJ, Stewart CF, Kocak M, et al. Phase I clinical trial of cilengitide in children with refractory brain tumors: Pediatric Brain Tumor Consortium Study PBTC-012. J Clin Oncol. 2008;26(6): 919-924.

118. Reardon DA, Fink KL, Mikkelsen T, et al. Randomized phase II study of cilengitide, an integrin-targeting arginine-glycine-aspartic acid peptide, in recurrent glioblastoma multiforme. $J$ Clin Oncol. 2008;26(34):5610-5617.

119. Gilbert MR, Kuhn J, Lamborn KR, et al. Cilengitide in patients with recurrent glioblastoma: the results of NABTC 03-02, a phase II trial with measures of treatment delivery. J Neurooncol. 2012;106(1): 147-153.

120. Albert JM, Cao C, Geng L, Leavitt L, Hallahan DE, Lu B. Integrin alpha v beta 3 antagonist Cilengitide enhances efficacy of radiotherapy in endothelial cell and non-small-cell lung cancer models. Int J Radiat Oncol Biol Phys. 2006;65(5):1536-1543.

121. Mikkelsen T, Brodie C, Finniss S, et al. Radiation sensitization of glioblastoma by cilengitide has unanticipated schedule-dependency. Int J Cancer. 2009;124(11):2719-2727.

122. ClinicalTrials.gov [homepage on the Internet]. ClinicalTrials.gov: A service of the US National Institutes of Health. Bethesda, MD: National Institutes of Health; Available from: http://www.clinicaltrials. gov. Accessed May 2013

123. Yarden Y. The EGFR family and its ligands in human cancer. Signalling mechanisms and therapeutic opportunities. Eur J Cancer. 2001; 37 Suppl 4:S3-S8.

124. Salomon DS, Brandt R, Ciardiello F, Normanno N. Epidermal growth factor-related peptides and their receptors in human malignancies. Crit Rev Oncol Hematol. 1995;19(3):183-232.

125. Libermann TA, Nusbaum HR, Razon N, et al. Amplification and overexpression of the EGF receptor gene in primary human glioblastomas. J Cell Sci Suppl. 1985;3:161-172.

126. Wong AJ, Bigner SH, Bigner DD, Kinzler KW, Hamilton SR, Vogelstein B. Increased expression of the epidermal growth factor receptor gene in malignant gliomas is invariably associated with gene amplification. Proc Natl Acad Sci U S A. 1987;84(19):6899-6903.

127. Lund-Johansen M, Bjerkvig R, Humphrey PA, Bigner SH, Bigner DD, Laerum OD. Effect of epidermal growth factor on glioma cell growth, migration, and invasion in vitro. Cancer Res. 1990;50(18): 6039-6044.

128. Barker FG Jr, Simmons ML, Chang SM, et al. EGFR overexpression and radiation response in glioblastoma multiforme. Int J Radiat Oncol Biol Phys. 2001;51(2):410-418.

129. Huang HS, Nagane M, Klingbeil CK, et al. The enhanced tumorigenic activity of a mutant epidermal growth factor receptor common in human cancers is mediated by threshold levels of constitutive tyrosine phosphorylation and unattenuated signaling. J Biol Chem. 1997;272(5):2927-2935.
130. Heimberger AB, Hlatky R, Suki D, et al. Prognostic effect of epidermal growth factor receptor and EGFRvIII in glioblastoma multiforme patients. Clin Cancer Res. 2005;11(4):1462-1466.

131. Feldkamp MM, Lala P, Lau N, Roncari L, Guha A. Expression of activated epidermal growth factor receptors, Ras-guanosine triphosphate, and mitogen-activated protein kinase in human glioblastoma multiforme specimens. Neurosurgery. 1999;45(6):1442-1453.

132. Liu M, Yang Y, Wang C, et al. The effect of epidermal growth factor receptor variant III on glioma cell migration by stimulating ERK phosphorylation through the focal adhesion kinase signaling pathway. Arch Biochem Biophys. 2010;502(2):89-95.

133. Lu KV, Zhu S, Cvrljevic A, et al. Fyn and SRC are effectors of oncogenic epidermal growth factor receptor signaling in glioblastoma patients. Cancer Res. 2009;69(17):6889-6898.

134. Bonavia $\mathrm{R}$, Inda MM, Vandenberg $\mathrm{S}$, et al. EGFRvIII promotes glioma angiogenesis and growth through the NF- $\kappa \mathrm{B}$, interleukin- 8 pathway. Oncogene. 2012;31(36):4054-4066.

135. Chakravarti A, Loeffler JS, Dyson NJ. Insulin-like growth factor receptor I mediates resistance to anti-epidermal growth factor receptor therapy in primary human glioblastoma cells through continued activation of phosphoinositide 3-kinase signaling. Cancer Res. 2002;62(1): 200-207.

136. Mendelsohn J, Baselga J. Epidermal growth factor receptor targeting in cancer. Semin Oncol. 2006;33(4):369-385.

137. Kim ES, Hirsh V, Mok T, et al. Gefitinib versus docetaxel in previously treated non-small-cell lung cancer (INTEREST): a randomised phase III trial. Lancet. 2008;372(9652):1809-1818.

138. Cappuzzo F, Ciuleanu T, Stelmakh L, et al; SATURN investigators. Erlotinib as maintenance treatment in advanced non-small-cell lung cancer: a multicentre, randomised, placebo-controlled phase 3 study. Lancet Oncol. 2010;11(6):521-529.

139. Vickers MM, Powell ED, Asmis TR, et al. Comorbidity, age and overall survival in patients with advanced pancreatic cancer - results from NCIC CTG PA.3: a phase III trial of gemcitabine plus erlotinib or placebo. Eur J Cancer. 2012;48(10):1434-1442.

140. van den Bent MJ, Brandes AA, Rampling R, et al. Randomized phase II trial of erlotinib versus temozolomide or carmustine in recurrent glioblastoma: EORTC brain tumor group study 26034. J Clin Oncol. 2009;27(8):1268-1274.

141. Rich JN, Reardon DA, Peery T, et al. Phase II trial of gefitinib in recurrent glioblastoma. J Clin Oncol. 2004;22(1):133-142.

142. Bianco C, Tortora G, Bianco R, et al. Enhancement of antitumor activity of ionizing radiation by combined treatment with the selective epidermal growth factor receptor-tyrosine kinase inhibitor ZD1839 (Iressa). Clin Cancer Res. 2002;8(10):3250-3258

143. Chinnaiyan P, Huang S, Vallabhaneni G, et al. Mechanisms of enhanced radiation response following epidermal growth factor receptor signaling inhibition by erlotinib (Tarceva). Cancer Res. 2005;65(8):3328-3335.

144. Sarkaria JN, Carlson BL, Schroeder MA, et al. Use of an orthotopic xenograft model for assessing the effect of epidermal growth factor receptor amplification on glioblastoma radiation response. Clin Cancer Res. 2006;12(7 Pt 1):2264-2271.

145. Chakravarti A, Dicker A, Mehta M. The contribution of epidermal growth factor receptor (EGFR) signaling pathway to radioresistance in human gliomas: a review of preclinical and correlative clinical data. Int J Radiat Oncol Biol Phys. 2004;58(3):927-931.

146. Harari PM, Huang SM. Epidermal growth factor receptor modulation of radiation response: preclinical and clinical development. Semin Radiat Oncol. 2002;12(3 Suppl 2):21-26.

147. Krishnan S, Brown PD, Ballman KV, et al; North Central Cancer Treatment Group. Phase I trial of erlotinib with radiation therapy in patients with glioblastoma multiforme: results of North Central Cancer Treatment Group protocol N0177. Int J Radiat Oncol Biol Phys. 2006;65(4):1192-1199.

148. Broniscer A, Baker SJ, Stewart CF, et al. Phase I and pharmacokinetic studies of erlotinib administered concurrently with radiotherapy for children, adolescents, and young adults with high-grade glioma. Clin Cancer Res. 2009;15(2):701-707. 
149. Brown PD, Krishnan S, Sarkaria JN, et al; North Central Cancer Treatment Group Study N0177. Phase I/II trial of erlotinib and temozolomide with radiation therapy in the treatment of newly diagnosed glioblastoma multiforme: North Central Cancer Treatment Group Study N0177. J Clin Oncol. 2008;26(34):5603-5609.

150. Schwer AL, Damek DM, Kavanagh BD, et al. A phase I dose-escalation study of fractionated stereotactic radiosurgery in combination with gefitinib in patients with recurrent malignant gliomas. Int J Radiat Oncol Biol Phys. 2008;70(4):993-1001.

151. Geyer JR, Stewart CF, Kocak M, et al. A phase I and biology study of gefitinib and radiation in children with newly diagnosed brain stem gliomas or supratentorial malignant gliomas. Eur J Cancer. 2010;46(18):3287-3293.

152. Pollack IF, Stewart CF, Kocak M, et al. A phase II study of gefitinib and irradiation in children with newly diagnosed brainstem gliomas: a report from the Pediatric Brain Tumor Consortium. Neuro-oncology. 2011;13(3):290-297.

153. Chakravarti A, Wang M, Robins HI, et al. RTOG 0211: a phase $1 / 2$ study of radiation therapy with concurrent gefitinib for newly diagnosed glioblastoma patients. Int J Radiat Oncol Biol Phys. 2013;85(5): 1206-1211.

154. Navé BT, Ouwens M, Withers DJ, Alessi DR, Shepherd PR. Mammalian target of rapamycin is a direct target for protein kinase B: identification of a convergence point for opposing effects of insulin and amino-acid deficiency on protein translation. Biochem $J$. 1999;344 Pt 2:427-431.

155. Fingar DC, Salama S, Tsou C, Harlow E, Blenis J. Mammalian cell size is controlled by mTOR and its downstream targets $\mathrm{S} 6 \mathrm{~K} 1$ and 4EBP1/eIF4E. Genes Dev. 2002;16(12):1472-1487.

156. Zhang S, Yu D. PI(3)king apart PTEN's role in cancer. Clin Cancer Res. 2010;16(17):4325-4330.
157. Khan KH, Yap TA, Yan L, Cunningham D. Targeting the PI3K-AKTmotor signaling network in cancer. Chim J cancer. 2013;32(5): 253-265.

158. Franz DN, Weiss BD. Molecolar therapies for tuberous selerosis and neurofibromatosis. Cover Neurol Neurosci Rep. 2012; 12(3): 294-302.

159. Eshleman JS, Carlson BL, Mladek AC, Kastner BD, Shide KL, Sarkaria JN. Inhibition of the mammalian target of rapamycin sensitizes U87 xenografts to fractionated radiation therapy. Cancer Res. 2002;62(24):7291-7297.

160. Anandharaj A, Cinghu S, Park WY. Rapamycin-mediated mTOR inhibition attenuates survivin and sensitizes glioblastoma cells to radiation therapy. Acta Biochim Biophys Sin (Shanghai). 2011;43(4): 292-300.

161. Kim KW, Mutter RW, Cao C, et al. Autophagy for cancer therapy through inhibition of pro-apoptotic proteins and mammalian target of rapamycin signaling. J Biol Chem. 2006;281(48):36883-36890.

162. Shinohara ET, Cao C, Niermann K, et al. Enhanced radiation damage of tumor vasculature by mTOR inhibitors. Oncogene. 2005;24(35):5414-5422.

163. Sarkaria JN, Galanis E, Wu W, et al. Combination of temsirolimus (CCI-779) with chemoradiation in newly diagnosed glioblastoma multiforme (GBM) (NCCTG trial N027D) is associated with increased infectious risks. Clin Cancer Res. 2010;16(22):5573-5580.

164. Sarkaria JN, Galanis E, Wu W, et al. North Central Cancer Treatment Group Phase I trial N057K of everolimus (RAD001) and temozolomide in combination with radiation therapy in patients with newly diagnosed glioblastoma multiforme. Int J Radiat Oncol Biol Phys. 2011;81(2):468-475.
OncoTargets and Therapy

\section{Publish your work in this journal}

OncoTargets and Therapy is an international, peer-reviewed, open access journal focusing on the pathological basis of all cancers, potential targets for therapy and treatment protocols employed to improve the management of cancer patients. The journal also focuses on the impact of management programs and new therapeutic agents and protocols on

\section{Dovepress}

patient perspectives such as quality of life, adherence and satisfaction. The manuscript management system is completely online and includes a very quick and fair peer-review system, which is all easy to use. Visit http://www.dovepress.com/testimonials.php to read real quotes from published authors. 